\title{
Psikolojik Güçlendirmenin Yenilikçi İş Davranışına Etkisi* (The Effect of Psychological Empowerment on Innovative Work Behavior)
}

\author{
İlknur ÇEVIK TEKIN ${ }^{\text {iD }}$ a Tahir AKGEMCI ${ }^{\text {iD }}$ b \\ a Selçuk Üniversitesi, Sosyal Bilimler Meslek Yüksekokulu, Konya, Türkiye. ilknurtekin@selcuk.edu.tr \\ b Selçuk Üniversitesi, İktisadi ve İdari Bilimler Fakültesi, Konya, Türkiye. takgemci@selcuk.edu.tr
}

\begin{tabular}{|c|c|}
\hline MAKALE BİLGİSİ & ÖZET \\
\hline $\begin{array}{l}\text { Anahtar Kelimeler: } \\
\text { Psikolojik Güçlendirme }\end{array}$ & $\begin{array}{l}\text { Amaç - Bu çalışmada Türkiye otomotiv sektöründe, psikolojik güçlendirmenin yenilikçi iş } \\
\text { davranışına etkisini ortaya koymak amaçlanmaktadır. }\end{array}$ \\
\hline $\begin{array}{l}\text { Gönderilme Tarihi } 27 \text { Mayıs } 2019 \\
\text { Revizyon Tarihi } 20 \text { Ağustos } 2019 \\
\text { Kabul Tarihi } 28 \text { Ağustos } 2019\end{array}$ & $\begin{array}{l}\text { Yöntem - Türkiye'de faaliyet gösteren otomotiv üreticisi firmalarda ampirik bir araştırma } \\
\text { gerçekleştirilmiştir. Araştırma, firmaların beyaz yakalı çalışanlarına, anket formu aracığıyla, basit } \\
\text { tesadüfi örneklem yöntemi ile uygulanmıştır. Psikolojik güçlendirme ile ilgili algıyı ölçmek için } \\
\text { Spreitzer (1995) tarafından geliştirilen "Psikolojik Güçlendirme Algısı" ölçeği yenilikçi iş } \\
\text { davranışını ölçmek için ise De Jong ve Den Hartog (2010) tarafından geliştirilen "Yenilikçi İş } \\
\text { Davranışı Ölçeği" kullanılmıştır. Elde edilen verilerin analizinde AMOS ve SPSS programlarından } \\
\text { yararlanılmıştır. }\end{array}$ \\
\hline \multirow[t]{2}{*}{$\begin{array}{l}\text { Makale Kategorisi: } \\
\text { Araştırma Makalesi }\end{array}$} & $\begin{array}{l}\text { Bulgular - Araştırma sonucunda, yeterlilik boyutu hariç, psikolojik güçlendirmenin diğer } \\
\text { boyutlarının, yenilikçi iş davranışını önemli ölçüde etkilediği sonucuna ulaşılmıstır. Anlam ile } \\
\text { özerklik \& etki boyutu yenilikçi iş davranışının her iki boyutuna da etki etmektedir. Ancak anlam } \\
\text { boyutu yaratıcılık ile ilgili fikir üretme \& araştırma boyutuna, fikri destekleme \& uygulama } \\
\text { boyutundan daha fazla etki ederken }(0,40>0,34) \text { özerklik\& etki boyutu, fikri destekleme \& } \\
\text { uygulama boyutuna fikir üretme \& araştırma boyutundan daha büyük oranda }(0,52>0,12) \text { etkisi } \\
\text { etki etmektedir. }\end{array}$ \\
\hline & $\begin{array}{l}\text { Tartışma - Psikolojik güçlendirmenin boyutları yenilikçi iş davranışının fikri destekleme \& } \\
\text { uygulama boyutuna \%52 etki ederken, yaratıcılık gerektiren fikir üretme \& araştırma boyutuna } \\
\text { \%21 düzeyinde etki etmektedir. Çalışanlarda psikolojik güçlendirmenin boyutlarının yenilikçi iş̧ } \\
\text { davranışının boyutlarına genel olarak pozitif ve anlamlı etkisinin olduğu bulgulanmıştır. Ancak } \\
\text { psikolojik güçlendirmenin yeterlilik boyutunun, yenilikçi iş davranışının hiçbir boyutuna etkisinin } \\
\text { olmaması araştırmanın önemli bulgularındandır. Çalışanların yaptıkları işlerle ilgili yeteneklerine } \\
\text { güvenmeleri, yenilikçi iş davranışlarını gerçekleştirmeleri için yeterli olmamaktadır. Psikolojik } \\
\text { güçlendirmenin gerçekleşmesi için çalışanlar işlerini anlamlı bulup, işin süreçlerine ve sonuçlarına } \\
\text { etki edip işle ilgili karar alımlarına katılmaları gerekmektedir. }\end{array}$ \\
\hline
\end{tabular}

\begin{tabular}{l} 
ARTICLE INFO \\
\hline Key Words: \\
Psychological Empowerment \\
Innovative Work Behavior \\
Automotive Industry \\
Automotive Manufacturers
\end{tabular}

Received 27 May 2019

Revised 20 August 2019

Accepted 28 August 2019

Article Classification:

Research Article

\section{ABSTRACT}

Purpose - In this study, it is aimed to demonstrate the impact of psychological empowerment on innovative work behavior in the Turkish automotive sector.

Design/methodology/approach - An empirical study was conducted in automotive manufacturer companies operating in Turkey. The research was applied to the White-collar employees of the firms by means of a survey form, using a simple random sampling method. "Perception of Psychological Empowerment" scale developed by Spreitzer (1995) was used to measure perception related to the psychological empowerment and "Innovative work Behavior Scale" developed by De Jong and Den Hartog (2010) was used to measure innovative work behavior. AMOS and SPSS programs were used in the analysis of the data obtained.

Findings - The research concluded that other dimensions of psychological empowerment, excluding the qualification dimension, significantly affect innovative work behavior. Meaning and autonomy \& impact dimensions influence both aspects of innovative work behavior. However, the meaning dimension has a greater impact on the creativity-related idea generation \& research dimension than on the idea Support \& Practice dimension $(0.40>0.34)$, while the autonomy\& impact dimension has a greater impact on the idea Support \& Practice dimension than on the idea generation \& research dimension $(0.52>0.12)$.

Discussion - Dimensions of psychological empowerment has an impact of $52 \%$ on the idea Support \& Practice dimension of innovative work behavior, while it has an impact of $21 \%$ on the idea generation \& research dimension that requires creativity. It has been found that the

*Bu makale, İlknur Çevik Tekin'in doktora tezinden üretilmiştir.

Önerilen Atıf/Suggested Citation:

Çevik Tekin, İ., Akgemci, T. (2019). Psikolojik Güçlendirmenin Yenilikçi İş Davranışına Etkisi, İşletme Araştırmaları Dergisi, 11 (3), $1674-$ 1692. 
dimensions of psychological empowerment in employees have a positive and meaningful effect on the dimensions of innovative work behavior in general. However, the fact that the competence dimension of psychological empowerment has no effect on any aspect of innovative work behavior is one of the important findings of the research. It is not enough for employees to rely on their ability to carry out innovative work behaviors. In order for psychological empowerment to take place, employees must find their work meaningful, influence the work processes and results and participate in work-related decision-making.

\section{Giriş}

Yönetim anlayışının hızla değiştiği ve organizasyon yapılarının yeniden şekillendiği günümüzde, değişen koşullara uyum sağlamak için işletmelerin yenilikçi olmaları kaçınılmazdır. Yenilikçilik değişim ve gelişimin itici gücüdür. Örgütsel yenilikçiliğin gerçekleşmesi çalışanların yenilikçi iş davranışı sergilemelerine bağlıdır. Örgütler son derece dinamik ve rekabetçi iş ortamı ile başa çıkmak için çalışanların yenilikçi potansiyellerinden yararlanmaları gerekmektedir (Akkoç, 2012: 48). Yeni fikirlerin, süreçlerin, ürün ya da hizmetlerin ortaya konulması, örgütlerce kabul edilmesi ve çalışanlar tarafından uygulanması olarak tanımlanan yenilikçilik aynı zamanda çalışanların önemli bir performans göstergesi ve iş çıktısıdır (Çelik vd., 2014: 492). Hızlı karar almanın öneminin her geçen gün arttı̆̆ı günümüz organizasyonlarında; karar alımına katılan, inisiyatif kullanabilen, hatta kendi kendine karar verebilen en önemlisi de verdiği kararlar neticesinde gelişen sonuçların sorumluluğunu üstlenebilen çalışanlara ihtiyaç olduğu açıtır. Bu durum çalışanların güçlendirilmesi ile mümkündür çünkü ancak psikolojik olarak güçlendirilmiş çalışanlar işin sahibi haline gelmektedirler. İşin sahibi haline gelen çalışanların almış oldukları kararlar neticesinde yenilikçi iş davranışlarına katkı sağlayıp sağlamadıklarının araştırılması bu çalı̧̧manın çıkış noktasını oluşturmaktadır. Çünkü eski yönetim anlayışında yenilik sadece belirli fonksiyonel sınıflandırmaların sorumluluğunda görülürken, günümüzün örgüt anlayışında tüm çalışanlardan yenilikçi davranışlar sergileyip bu davranışları içselleştirmeleri beklenmektedir. Çünkü yenilikçi iş davranışlarına sahip çalışanların var olduğu yaratıcı örgütler rakiplerine göre, büyük oranda rekabet avantajı elde etmektedirler.

Örgütler tarafından rekabet avantajı elde etmenin kilit unsuru görülen çalışanların yenilikçi iş davranışlarını pek çok faktör etkilemektedir. Bu çalışmada psikolojik güçlendirmenin yenilikçi iş davranışı üzerinde etkisi ele alınıp, incelenecektir. Çalışma sonuçlarının araştırmacılar ve uygulayıcılar için faydalı olması beklenmektedir.

\section{Literatür Özeti}

\subsection{Güçlendirme Kavramı}

Bir yönetim kavramı olarak güçlendirme, yardımlaşma, paylaşma, yetiştirme ve ekip çalışması yolu ile çalışanların karar vermelerini, inisiyatif kullanabilmelerini ve sorumluluk alabilmelerini sağlayarak işgörenleri işin sahibi haline getirmeyi amaçlar. Güçlendirme çalışanların haklarını, dolayısıyla yetkilerini, artırma ve çalışanları geliştirme sürecidir (Barutçugil, 2004: 398; Koçel, 2013: 474). Güçlendirme, yöneticilerin kendilerini ve organizasyonu etkileyen kararlar almak için gerekli olan gücü elde etmeleri ve kullanmaları için başkalarına yardım etme sürecidir. Başka bir deyişle, güç yöneticiler tarafından çalışanlara verilir (Schermerhorn vd., 2000: 319).

Tschohl (1997)'ye göre, bir çalışan örgütten ziyade müşteri tatminini sağlamak için nasıl davranması gerektiğini bilip, bunu anında kimseye danışmadan yapabiliyorsa, güçlendirilmiştir. Eğer bir örgütte müşteri kazanmıyorsa yani çalışanlar güçlendirilmemişse örgüt kaybediyordur (Doğan, 2006: 103). Rosabeth Kanter, "Men and Women of the Corporation" isimli kitabında güçlendirme için "bir çalışanın amaçlara ulaşmak için mevcut kaynaklardan yararlanma ve bağımsız şekilde kararlar alma yeteneğidir" demiştir (Tolay vd., 2012: 451).

Güçlendirme kavramının tek bir boyut olarak ifade edilmesinin güçlüğü fark edilmiş ve yapılan çalışmalar neticesinde, güçlendirme konusundaki yaklaşımlar "Yapısal Güçlendirme" ve "Psikolojik Güçlendirme" olarak ikiye ayrılmıştır. Genel olarak Spreitzer tarafından geliştirilen psikolojik güçlendirme bireye odaklanırken, Kanter tarafından geliştirilen yapısal güçlendirme örgüte yoğunlaşmaktadır (Wiens, 2012: 23). Psikolojik güçlendirme, çalışanların örgütte var olan yapısal güçlendirme koşularını ne şekilde yorumladıkları ile ilgili bilişsel bir algıdır. Burke ve arkadaşları (1986) güçlendirme ile ilgili yetki devretme eylemine işaret ederken, Thomas ve Velthouse (1990), güçlendirilmiş bireyin içsel durumunu (psikolojik 


\section{İ. Çevik Tekin - T. Akgemci 11/3 (2019) 1674-1692}

güçlendirme) ima eder (Menon, 2001: 154). Güçlendirme, davranışsal (yapısal) yaklaşıma göre, güç ve karar verme yetkisinin çalışanlara verilmesidir. Ancak kimi zaman yöneticilerin çalışanlara karşı davranış amaçları ile çalışanların bu davranışları nasıl algıladıkları birbiri ile oldukça farklı olabilmektedir. Bundan dolayı, güçlendirme daha sonra bilişsel (psikolojik) bir yaklaşım ile açıklanmış ve çalışanları güçlendirmek amacıyla yöneticilerin uyguladıkları yöntemlerin çalışanlarca nasıl algılandığı ile ilişkilendirilmiştir (Gümüşlüoğlu ve Aygün, 2010: 25).

\subsection{Psikolojik Güçlendirme}

Psikolojik güçlendirme, bireyin kendi ideallerine veya standartlarına göre değerlendirilen bir çalışma amacının değeridir. Yüksek güçlendirmeye sahip çalışanların, düşük güçlendirmeye sahip çalışanlara kıyasla işlerinde daha çok motive olması beklenir (Gümüşlüoğlu ve Aygül, 2010: 25). Spreitzer (1995, 1996), psikolojik güçlenmeyi içsel görev motivasyonu ile açıkça eşitlemektedir (Menon, 2001: 175). Conger (1989)'a göre, psikolojik güçlendirme kişisel yetkinliği algılayarak içsel inançları güçlendirmeyi ve değiştirmeyi içeren bir süreçtir (Conger, 1989: 18). Çalışanlar tarafından algılanan rollere ilişkin organizasyonun başarısını belirleyen girişimlerdir. Thomas ve Velthouse (1990) psikolojik güçlenmeyi içsel motivasyon olarak tanımlayarak, bireyin kendi rolüne olan yönünü yeniden tanımlayan bilişleri ortaya çıarmıştır. Thomas ve Velthouse (1990) ve Spreitzer (1995) güçlenmenin çok yönlü olduğunu ve özünün tek bir kavram tarafından ele geçirilemeyeceğini savunmuşlardır. Bireyin iş rolüne yönelimini yansıtan dört biliş dizisinden oluştuğunu ifade etmişlerdir. Bunlar; anlam, yetkinlik (yeterlilik, özyeterlilik), otonomi (seçim, özerklik) ve etkidir (Spreitzer, 1995: 1443). Psikolojik olarak güçlendirilmiş bireyler kendilerini yetkin hissetme, işlerini ve çalışma ortamlarını anlamlı şekilde etkileme, proaktif davranışları kolaylaştırma, inisiyatif kullanma, bağımsız olarak faaliyet gösterme yetkinliğine sahiptirler (Spreitzer, 1995; Thomas ve Velthouse, 1990).

Bu çalışmada psikolojik güçlendirmenin boyutları Spreitzer $(1995,1996)$ sınıflandırmasına göre, anlam, yeterlilik, otonomi ve etki olarak ele alınmıştır.

\subsubsection{Anlam}

Anlam, çalışanın işinin rolünün gerektirdikleri ile inançları, değerleri, davranışları ve tutumları arasındaki uyuma işaret eder (Spreitzer, 1996: 484). Örgütsel görevlerin çalışanlar için taşıdığı değerdir. Anlamlılığın düşük derecede olması, çalışanın önemli olaylar karşısında kendisini işlevsiz ve değersiz hissetmesine neden olur ve bu durum çalışanın olaylara karşı duyarsız kalmasıyla sonuçlanır. Yüksek derecede anlamlılı̆̆ın algılanması durumunda çalışanda bağlılık, katılım ve enerjinin artması beklenmektedir (Thomas ve Velthouse, 1990: 672-673).

\subsubsection{Yeterlilik (Yetkinlik-Özyeterlilik)}

Çalışanların bir görevi başarabileceklerine yönelik taşıdıkları inançtır (Spreitzer, 1995: 1443). Thomas ve Velthouse (1990) "Yeterlilik" kavramının isimlendirilmesinde, "öz-etki" ve "çalışanın uzmanlığı" terimleri kullanmışlardır. Yeterlilik, çalışanın işini doğru yapması ile ilgili kendine olan inanç ve güvenidir. Çalışanın yeterliliğine ilişkin tereddütleri varsa ya da çalışan düşük düzeyde özgüvene sahipse yeteneklerini kullanmayı gerektirecek durumlardan kaçınacaktır (Thomas ve Velthouse, 1990: 673). Çalışanların, işlerini iyi bir şekilde yapabilmeleri için gerekli bilgi ve becerilere sahip olduklarına dair inancını yansıtır. Conger ve Kanungo (1988) güçlendirmeyi, öz yeterlilikle ilgili motivasyonel bir kavram olarak ifade ederken, Spreitzer (1995) güçlendirmeyi, örgütte faaliyet gösteren çalışanların öz yeterlilik duygularının artırılması şeklinde ifade etmiştir (Conger ve Kanungo, 1988: 477).

\subsection{3. Özerklik (Seçim- Otonomi)}

Özerklik, çalışanların işlerini nasıl yapacaklarını kendilerinin belirleyebilme özerkliklerinin olmasıdır. İşteki rolünü sergilerken özerk hareket edebilmesidir (Spreitzer, 1996: 484). Yetkinlik bir iş ile ilgili ustalık ya da uzmanlık olarak ifade edilebilirken, özerklik çalışanın işini başlatma, devam ettirme ve düzeltme gibi konularda inisiyatif kullanabilmesi ile ilgili bir algıdır (Hu ve Leung, 2003: 368).

Çalışanın çalışma yöntemleri hakkında kendisinin karar vermesi otonomi boyutuna örnek olabilir (Spreitzer, 1995: 1443). Çünkü otonomi (özerklik) bir kişinin eylemlerini başlatmakta ve düzenlemektedir. Bu sayede çalışan faaliyetleri ile ilgili inisiyatif kullanıp ve söz konusu faaliyetler üzerinde düzenleme yapabilmektedir (Deci vd., 1989). Thomas ve Velthouse (1990)'a göre, yaptı̆̆ işle ilgili özerk bir şekilde davranabilen, işleri 


\section{İ. Çevik Tekin - T. Akgemci 11/3 (2019) 1674-1692}

nasıl yapacağı ile ilgili seçimlerini kendisi yapabilen bir çalışan, güçlendirilmiş olmasının yanı sıra yaratıcı ve yenilikçi de olacaktır. (Thomas ve Velthouse, 1990: 674).

\subsubsection{Etki}

Etki, çalışanın bireysel olarak, yönetsel düzeydeki stratejik ve operasyonel sonuçlara etki edebilme derecesidir (Spreitzer, 1995: 1443-1444). Özerklik (otonomi) çalışanın kendi işi ile ilgili kontrol iken, etki boyutu ise çalışanın örgütsel sonuçlar üzerinde kontrole sahip olması ile ilgilidir. Dolayısıyla etki aynı zamanda, çalışanın bütün düzeylerde karar verebilme ve işlerin süreçlerini ve sonuçlarını etkileyebilmesine olan inancını ifade eder (Sigler ve Pearson, 2000: 29).

Bu dört boyut (anlam, yeterlilik, otonomi ve etki) birlikte içsel görev motivasyonu sağlamakta ve her bir boyutun yüksek düzeyde algılanması çalışanda genel olarak psikolojik güçlendirme ile sonuçlanmaktadır (Şen, 2008: 33). Bu boyutlardan birinin eksik olması güçlendirmeyi tamamen ortadan kaldırmasa da güçlendirmenin derecesini azaltmaktadır ( $\mathrm{Hu}$ ve Leung, 2003: 368). Örneğin çalışan, işleri ile ilgili faaliyetlere etkisinin olduğunu (etki boyutu) düşünmesine rağmen işini iyi yapmak için yeterli düzeyde yeteneğe (yeterlilik boyutu) sahip olmadığına inanıyorsa, yeteri kadar güçlendirilmiş olmayacaktır (Spreitzer, 2007: 8).

\subsection{Yenilik Kavramı}

İşletme disiplininde yenilik kavramını inceleyen ilk çalışma ise 1969 yılında Muse ve Kegerreis tarafından "yeni ürün geliştirme" konusunda yapılmıştır. Çalışmada, Ar-Ge çalışmalarının ve yeni ürünlerin işletmelerin pazarlama faaliyetlerinin başarısına olan etkileri incelenmiştir. Söz konusu çalışmada, yenilik kavramı "yeni ürün geliştirme" olarak ifade edilmektedir (Şahin, 2009: 260).

Literartürde yenilik kavramı pek çok açıdan ele alınıp çeşitli tanımlamalar yapılmıştır.

Cumming'e göre yenilik, etkili ve kârlı olan bir ürün ya da hizmetin müşteri memnuniyeti sağlamadan önce başarılı ilk kullanımıdır (Cumming, 1998: 22).

Birkinshaw ve arkadaşlarına (2008) göre yenilik, örgütsel değişimin belirli bir şeklini ifade eder. Örgütle ilgili bazı faaliyetlerin; şekil, kalite veya yönetsel açıdan zaman içerisinde değişimdir. Kısacası yenilik için geçmişten uzaklaşmadır denilebilir (Birkinshaw vd., 2008: 826).

Yenilik, bazen yaratıcılık sürecinin sonunda elde edilirken, bazen de, rakiplerden, müşterilerden ya da tedarikçilerden elde edilen fikirlerin ticarileştirilmesidir (Özdaşlı, 2005: 74-75).

Yenilik, yeni bir fikir edinme ve uygulamaya koyma sürecidir. Aynı zamanda yenilik = rekabet avantajı olarak formüle edilebilir (Schermerhorn, 1999: 377-379).

Yenilik, bir örgütün pazara yeni ürün sunması veya yenilikçi davranış ve stratejik yönelim yoluyla yeni pazarlara açılmasıdır (Wang ve Ahmed, 2004: 304).

Drucker yeniliği, bir örgütte birlikte çalışan farklı bilgi ve yetenekteki insanları verimli hale getirmek için onlara ilk defa olanak sağlayan yararlı bilgi şeklinde tanımlamıştır. Yenilik bir bilim veya teknolojiden ziyade bir değerdir. Yenilik çevrenin etkinliğini dikkate almak zorundadır. Yenilik, örgütün dışını hesaba katmadan yalnızca örgüt içinde oluşan olgu değildir. Yenilik çevre üzerinde ne kadar etkin ise o kadar değerlidir (Durna, 2002: 5). Yenilik kendisinin değer olmasının yanı sıra örgüte değer katar.

\subsection{Yenilikçi İş Davranışı}

Kökeni West ve Farr (1989)'a dayanan yenilikçi iş davranışı, rol performansına, gruba ya da organizasyona fayda sağlamak amacıyla; bir iş rolü, grup ya da organizasyon içinde yeni fikirlerin kasıtlı olarak yaratılması, tanıtılması ve uygulanmasıdır. West ve Farr (1989)'un ardından Scott ve Bruce (1994)'de, iş yerindeki yenilikçi iş davranışı, üç farklı davranışsal görev, fikir üretimi, fikir tanıtımı ve fikir gerçekleştirme gibi bir dizi kümeden oluşan karmaşık bir davranış olarak tanımlamaktadır (Janssen, 2005: 575).

Genel bir tanımla yenilikçi iş davranışı, çalışanların bilinçli olarak yeni fikirleri, ürünleri, işlemleri ve prosedürleri kendi çalışma rolüne, çalışma birimine veya organizasyonuna tanıtması ya da uygulamasıdır. $\mathrm{Bu}$ tür davranışlara örnekler; yeni teknoloji araçlarını araştırmak, hedeflere ulaşmak için yeni yollar 


\section{İ. Çevik Tekin - T. Akgemci 11/3 (2019) 1674-1692}

önermek, yeni çalışma yöntemleri ve yeni fikirleri uygulamak için ilgili kaynakları araştırma ve güvence altına almaktır (Yuan ve Woodman. 2010: 324).

Yenilikçi iş davranışları çalışanlar için her yeniliğin köşe taşı olarak görülebilir. Yenilikçi davranışlar dinamik bir ortamda geliştikçe örgütsel süreçlerin etkinliği ve şirketin başarısı için hayati önem taşırlar ayrıca ortaya çıkan sorunların üstesinden gelmeye yardımcı olup rekabet avantajı sağlarlar. Yenilikçi iş davranışları ile ilgili bazı araştırmacılar yaratıcılık terimini kullanırken, bazı araştırmacılar sıklıkla ilk kez yapılan bir şeye vurgu yaparlar (Woodman vd., 1993). Çalışanlar işlerinin yenilik gerektirdiğini fark ettiğinde, yenilikçi davranış ile meşgul olacaklardır. Yenilikçi davranışın belirleyicisi pek çok değişken olsa da yaratıcılık yenilikçi davranışı açıklayabilecek en temel unsurlarından biridir (Yuan ve Woodman, 2010: 323). Yenilikçi davranışlar çalışanın bir problemi tanımladığı aşamada başlar, daha sonra problem ile ilgili yeni fikirler ürettiği, nihayetinde bu uygulamalardan faydalanmak ve onları kullanmak amaciyla uygun bir model geliştirdiği çok fazlı bir süreçtir (Turek, 2012: 73). Kısacası, yeni uygun fikirlerin, süreçlerin ve çözümlerin üretilmesi, tanıtımı ve uygulanmasından oluşan bir davranıştır (Prieto ve Perez Santana, 2014: 189).

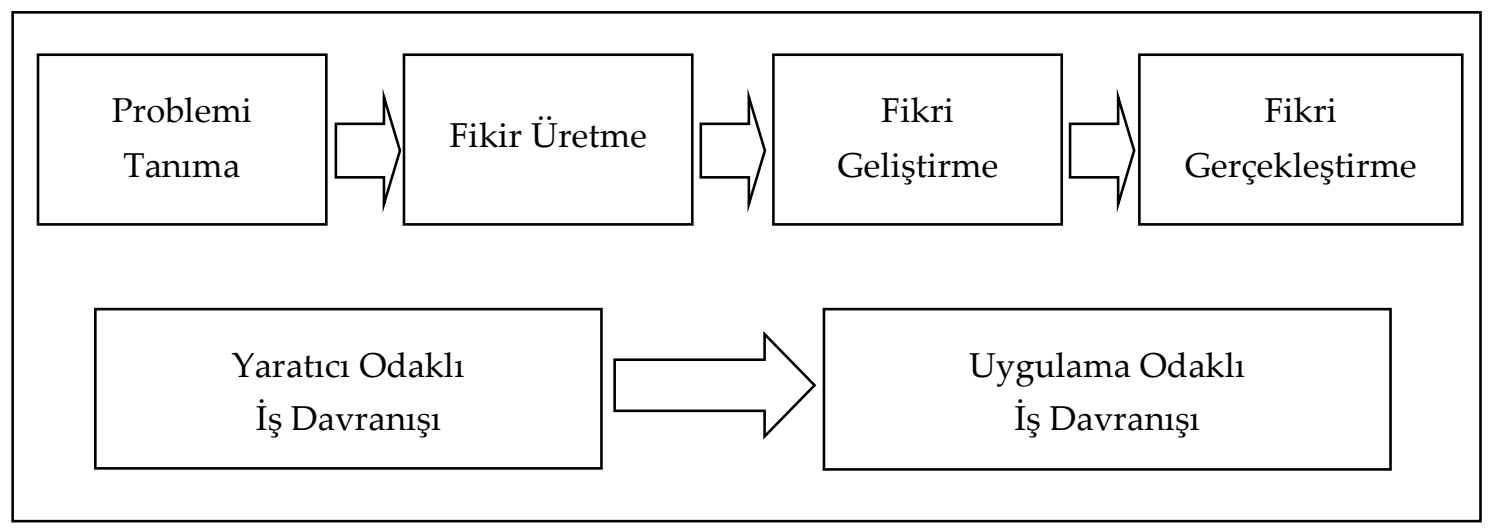

Şekil 1. Yenilikçi İş Davranışlarının Dört Aşaması

Kaynak: Janssen vd., 1997; Oukes, 2010: 15.

Şekil 1'de de gösterildiği gibi, yenilikçi iş davranışının ilk iki aşaması, çalışanın işle ilgili sorunları tanıması ve anlamasıyla başlayıp, kendi iş bağlamında yeni ve faydalı fikirleri üretmesiyle devam eden yaratıcı odaklı iş davranışı kavramını ortaya koymaktadır. Son iki aşama, potansiyel tartışmalara (örneğin, meslektaşlar ve yöneticiler) yeni bir fikrin teşvik edilmesi ve sonuçta iş-rol, grup veya topluluğun içinde toplanan gerçek fikirlerin gerçekleştirilmesini kapsayan uygulama odaklı iş davranışlarına atıfta bulunur (Dorenbosch vd., 2005: 130).

\section{Psikolojik Güçlendirme ve Yenilikçi İş Davranışı}

Literatürde, psikolojik güçlendirme ve yenilikçi iş davranışı ilişkisini konu edinen araştırmalara bakıldığında; İlk çalışma Bass (1985)'e aittir. Çalışma sonucunda, psikolojik güçlendirmenin özerklik \& etki boyutunun yenilikçi davranışlarla ilişkili olduğu bulgulanmıştır. Spreitzer (1995) yılında Fortune 50 listesinde yer alan işletmelerden 393 yöneticiye yaptığı çalışmasında güçlendirme ile yenilikçi davranışlar arasında pozitif ve anlamlı ilişkiler tespit etmiştir. Psikolojik güçlendirmenin gerçekleşmesi için ödüller, bilgi paylaşımı ve öz-saygının gerekliliğinden bahsetmiş ve psikolojik güçlendirmeyi anlam, yeterlilik, özerklik ve etki olarak sınıflandırmıştır. Redmond ve çalışma arkadaşları 1993 yılında yaptıkları çalışmada psikolojik güçlendirme ile yenilikçi iş davranışı arasında yine pozitif ilişkiler bulgulamışlardır. Ayrıca özyeterliliği yüksek ve işi benimsemiş çalışanların daha fazla yenilikçi davranış sergileyeceklerini belirtmişlerdir. Çekmecelioğlu ve Eren (2007) psikolojik güçlendirmenin anlam, özerklik ve etki boyutlarının yaratıcı davranışları pozitif yönde etkilediğini bulgulamışlardır. Çavuş ve Akgemci (2008) çalışmalarında, psikolojik güçlendirmenin boyutlarının örgütlerde yaratıcı ve yenilikçi davranışları artırdığını bulgulamışlardır. Çetin ve Evcim (2009) tarafından yapılan bir çalışmada, psikolojik güçlendirmenin boyutları ile yenilikçi davranışın boyutları arasında pozitif ve anlamlı ilişkiler bulgulamışlardır. Knol ve VanLinge (2009) psikolojik güçlendirmenin örgütteki yenilikçi davranışı artırdığını bulmuşlardır. Ayrıca çalışmada psikolojik 


\section{İ. Çevik Tekin - T. Akgemci 11/3 (2019) 1674-1692}

güçlendirme, yapısal güçlendirme ve yenilikçi davranış arasında aracı işlev görmüştür. Pieterse ve diğerlerinin 2010 yılında Hollanda'da kamu kurumunda çalışan 230 kişiye uyguladıkları çalışmada, çalışanların psikolojik güçlendirme algılarının yenilikçi iş davranışlarını artırdığını bulgulamışlardır. Gürbüz'ün 2012 yılında yaptığı tez çalışmasına göre, çalışanlara uygulanan davranışsal, psikolojik, sosyal ve yapısal güçlendirmelerin çalışanların yenilikçilik algıları üzerinde pozitif ve anlamlı etkisi bulunmaktadır. Uzunbacak (2013) çalışmasına göre ise çalışanların davranışsal, psikolojik, sosyal ve yapısal güçlendirmelerinin yenilikçilik algıları üzerinde pozitif ve anlamlı etkisi bulunmaktadır. Ayrıca, güçlendirmenin tüm boyutlarının birlikte uygulanmasının yenilikçiliğe etkisi oldukça yüksek düzeydedir. Oktuğ, 2014 yılında yaptığı çalışmasında yenilikçilik eğilimindeki artışın çalışmaya tutkunluk düzeyine katkı sağlayabileceği, örgüt içinde psikolojik güçlendirmenin varlığıyla da bu ilişkinin artırılabileceği sonucunu elde etmiştir. Çekmecelioğlu ve Özbağ 2014 yılında yaptıkları çalışmada çalışanların güçlendirilmesinin bireysel yaratıcılık ve firma yenilikçiliğini olumlu yönde etkileyebileceğini bulmuşlardır. Özkan (2017), çalışanların özyeterlilik düzeyinin yaratıcı ve yenilikçi iş davranışlarına etkisini perakende, finans, enerji ve havacılık sektörlerinde faaliyet gösteren çalışanlarda araştırmıştır. Çalışma sonucunda çalışanlarda var olan özyeterlilik algısının, yaratıcı ve yenilikçi davranışlar üzerinde pozitif etki sağladığı bulgulanmıştır. Tüm bu çalışmaların ortak noktası, işletmelerde var olan psikolojik güçlendirme anlayışının çalışanların ve yöneticilerin yenilikçilik algılarını ve yenilikçi iş davranışlarını artırdığıdır. Çünkü yenilikçi anlayışın hâkim olduğu örgütlerde çalışanlar işlerin yapılmasına karar verme ve yeni fikirler üretme yetkisine sahiptirler (Doğan, 2003: 25).

\section{Metodoloji}

\subsection{Araştırmanın Amacı}

Yeni fikirlerin, süreçlerin, ürün ya da hizmetlerin ortaya konulması, örgütlerce kabul edilmesi ve çalışanlar tarafından uygulanması olarak tanımlanan yenilikçilik aynı zamanda çalışanların önemli bir performans göstergesi ve iş çıktısıdır. Yenilikçi iş davranışı, çalışanların bilinçli olarak yeni fikirleri, ürünleri, işlemleri ve prosedürleri kendi çalışma rolüne, çalışma birimine veya organizasyonuna tanıtması ya da uygulamasıdır Çalışanların yenilikçi iş davranışlarını başta çalışanların kişisel özellikleri olmak üzere işe ve örgüte ilişkin birçok faktör etkileyebilmektedir (Çelik vd., 2014: 492). Bu çalışmada, çalışanların yenilikçi iş davranışları üzerinde psikolojik güçlendirmenin etkisi incelenecektir. Bu nedenle araştırmanın ana problemi, çalışanların psikolojik olarak güçlendirilmesi, yenilikçi iş davranışlarını etkiler mi? olarak belirlenmiştir.

\subsection{Araștırmanın Yöntemi}

Çalışmanın araştırma tasarımı nicel araştırmadır. Araştırma için gerekli olan veriler ise nicel araştırma yönteminin tekniklerinden biri olan anket yöntemi kullanılarak toplanmıştır. Anket üç bölümden oluşmaktadır. İlk bölüm, ankete katılan katılımcıların demografik özelliklerinin tespit edildiği bölümdür. Bu bölümde toplam 9 soru sorulmuştur. Bu bölümdeki soruların bazıları (yaş, çalışma süresi, çalışan sayısı, çalıştıkları departman) açık uçlu olarak yöneltilip analizlerde kolaylık sağlaması açısından sonradan gruplandırılmıştır. İkinci bölüm psikolojik güçlendirme ölçeğine ilişkin maddelerin olduğu bölümdür. Bu bölümde 12 madde bulunmaktadır. Üçüncü bölüm ise çalışanların yenilikçi davranış ile ilgili algılarının tespit edildiği bölümdür. Bu bölümde toplam 10 soru sorulmuştur. Psikolojik güçlendirme ile ilgili literatürde en sık başvurulan ölçek olmasından dolayı Spreitzer $(1995,1996)$ tarafından geliştirilen "Psikolojik Güçlendirme Algısı" soru formu kullanılmıştır. Yenilikçi iş davranışı ile ilgili ise De Jong ve Den Hartog tarafından 2008 yılında 17 madde olarak geliştirilip, 2010 yılındaki çalışmalarında 10 madde olarak kullandıkları "Yenilikçi İş Davranışı Ölçeği" nin kısa formu kullanılmıştır. Ölçekler, "1. Kesinlikle katılmıyorum" seçeneğinden " 5 . Kesinlikle katılıyorum" seçeneğine kadar sıralanan 5'li Likert tipi ölçek niteliğindedir.

\subsection{Araştırmanın Evreni ve Örneklem}

Çalışmanın evrenini, Türkiye'de üretim yapan otomotiv firmalarının beyaz yakalı çalışanları oluşturmaktadır. Ölçme aracında yer alan soruların tam olarak, doğru anlaşılması ve güvenilir cevaplanması çalışma için önemlidir. Bu nedenle araştırmanın evreni yalnızca beyaz yakalı çalışanlarla sınırlı tutulmuştur. Aynı zamanda, günümüzde bilginin ve teknolojik gelişimin öneminin her geçen gün artmasıyla birlikte, kas 


\section{İ. Çevik Tekin - T. Akgemci 11/3 (2019) 1674-1692}

gücü yerini zihinsel güce bırakmıştır. Bu nedenle ekonomik üretimin başlıca aktörleri mavi yakalı çalışanlar yerine beyaz yakalı çalışanlar olmasından dolayı da bu çalışanlardan veri toplanmıştır.

İstediğimiz kriterlere uygun firmaların belirlenmesinde, Otomotiv Sanayi Derneği (OSD) ve çeşitli internet kaynaklarından yararlanılmıştır. Belirlenen kriterlere uygun Türkiye'de faaliyet gösteren on altı otomotiv firması bulunmaktadır. Türkiye otomotiv sektörü 12 firma ile 18 fabrikada faaliyetlerini sürdürmektedir. Bu 12 firmanın 4'ü yalnızca otomobil, 6'sı sadece ticari araç, 2'si ise hem otomobil hem de ticari araç üretimi yapmaktadır. Sektörle ilgili çeşitli kaynakların incelenmesi ve uzman görüşlerinin alınması neticesinde, traktör üretimi yapan 4 firma da çalışmaya dâhil edilip, çoğunluğu Marmara bölgesinde yer alan 16 firmanın beyaz yakalı çalışanlarına basit tesadüfi örnekleme yöntemi ile anket uygulaması yapılmıştır.

Örneklemin, alındığı evreni temsil etmesi önemlidir. Yeterli bir örneklem sayısı, araştırma neticesinde güvenilir sonuçlar sağlayacak kadar veri içeren örneklemdir. Alınan örneklemin evreni temsil edemediği durumlarda örnekleme hatası oluşmaktadır. (Young, 1968: 324). Uygulama yapılan firmaların toplam çalışan sayısı, İKY departmanı ile yapılan görüşmeler ve çalışanlara yöneltilen sorular neticesinde yaklaşık 73.000 olarak hesaplanmıştır. Otomotiv sektöründe faaliyet gösteren beyaz yakalı çalışan sayısını belirtmek, firmaların bazı bilgilerini paylaşmak istememeleri nedeniyle mümkün olamamaktadır. Bu bağlamda örneklemin hesaplanmasında Tablo 1'de yer alan örneklem büyüklüklerinden faydalanılmıştır.

Tablo 1. Örneklem Hesaplanması ile İlgili Tablo

\begin{tabular}{ll}
\hline Evren Sayıs & Örneklem Sayıs \\
\hline 10 & 10 \\
100 & 80 \\
200 & 132 \\
500 & 217 \\
1.000 & 278 \\
1.500 & 306 \\
2.000 & 322 \\
3.000 & 341 \\
5.000 & 357 \\
10.000 & 370 \\
15.000 & 375 \\
20.000 & 377 \\
50.000 & 381 \\
100.000 & 384 \\
1.000 .000 & 384 \\
10.000 .000 & 384 \\
\hline
\end{tabular}

Kaynak: Cohen, Manion ve Morrison, 2000; Sekaran, U. ,2000.

Tablo 1'de görüldüğü gibi, çalışmanın örneklem sayısı 384 olarak belirlenmiştir. Çalışma kapsamında en az 384 beyaz yakalı çalışana ulaşıldığı takdirde araştırmada belirlenen örneklemin evreni temsil ettiği sonucuna ulaşılacaktır. Aynı zamanda YEM'de uygun örneklem büyüklüğünün hesaplanabilmesi için, Hair ve arkadaşları (2010), 100- 400 arasında örneklem büyüklüğünü "yeterli örneklem" olarak kabul etmektedirler. Kline (2011)'e göre, YEM'de normal dağılım sergilemek şartıyla 100 örneklem "en az olması gereken değer"dir ve genellikle YEM analizi ile yapılmış çalışmalarda 200 örneklem "yeterli örneklem" olarak kabul edilmektedir (Kline, 2011: 12). Bu açılamalardan sonra YEM uygulanması için örneklem büyüklüğünün 100 ile 400 arasında olması gerektiği sonucuna ulaşılabilir. Çalışma ile ilgili 420 anket uygulanmıştır ancak uç değer analizinden sonra 406 anket çalışma kapsamında kullanılmıştır. 


\section{Veri Analizi ve Bulgular}

\subsection{Demografik ve iş ile ile İlgili Bulgular}

Anketi cevaplayan beyaz yakalı çalışanların demografik bulgularının yer aldığı Tablo 2 incelendiğinde 406 katılımcının çoğunluğunun erkek (\%88), evli (\%83) ve 36-40 yaş (\%24) aralığında ve lisans seviyesinde (\%78) eğitime sahip olduğu görülmektedir. Katılımcıların işle ilgili özellikleri incelendiğinde çoğunluğunun üretim (\%38) departmanında faaliyet gösterdiği ve 9001 ve üzeri (\%53) çalışan sayısına sahip firmalarda çalıştıkları görülmektedir.

Tablo 2. Katılımcıların Demografik ve İşle İlgili Özellikleri

\begin{tabular}{|c|c|c|c|}
\hline & & Frekans & Oran (\%) \\
\hline \multirow{2}{*}{ Cinsiyet } & Kadın & 48 & 11,8 \\
\hline & Erkek & 358 & 88,2 \\
\hline \multirow{2}{*}{ Medeni Durum } & Evli & 337 & 83,0 \\
\hline & Bekâr & 69 & 17,0 \\
\hline \multirow{8}{*}{ Yaş } & 25 alt1 & 12 & 3,0 \\
\hline & $26-30$ & 62 & 15,3 \\
\hline & $31-35$ & 83 & 20,4 \\
\hline & $36-40$ & 99 & 24,4 \\
\hline & $41-45$ & 51 & 12,6 \\
\hline & $46-50$ & 46 & 11,3 \\
\hline & $51-54$ & 34 & 8,4 \\
\hline & 55 ve üzeri & 19 & 4,7 \\
\hline \multirow{5}{*}{ Eğitim Durumu } & Lise & 7 & 1,7 \\
\hline & Ön lisans & 20 & 4,9 \\
\hline & Lisans & 316 & 77,8 \\
\hline & Yüksek lisans & 49 & 12,1 \\
\hline & Doktora & 14 & 3,4 \\
\hline \multirow{7}{*}{ Çalıştığınız Departman } & Yönetim & 85 & 20,9 \\
\hline & Üretim & 154 & 37,9 \\
\hline & Ar-Ge & 64 & 15,8 \\
\hline & İKY & 10 & 2,5 \\
\hline & Satış / pazarlama & 36 & 8,9 \\
\hline & Muhasebe Finans & 27 & 6,7 \\
\hline & Diğger & 30 & 7,4 \\
\hline \multirow{5}{*}{ İşletmede Çalışan Sayısı } & $1000-3000$ & 20 & 4,9 \\
\hline & $3001-5000$ & 21 & 5,2 \\
\hline & $5001-7000$ & 123 & 30,3 \\
\hline & $7001-9000$ & 27 & 6,7 \\
\hline & 9001 ve üzeri & 215 & 53,0 \\
\hline \multirow{3}{*}{ İşletmenin Sermaye Yapısı } & Tamamen yerli & 72 & 17,7 \\
\hline & Tamamen yabancı & 38 & 9,4 \\
\hline & Yabancı ortaklık & 296 & 72,9 \\
\hline \multirow{6}{*}{ İşletmede Çalışma Süresi } & $0-3$ yil & 53 & 13,1 \\
\hline & $4-7$ y1l & 107 & 26,4 \\
\hline & $8-11$ yıl & 102 & 25,1 \\
\hline & $12-15$ y1l & 121 & 29,8 \\
\hline & $16-19$ y1l & 23 & 5,7 \\
\hline & Toplam & 406 & 100,0 \\
\hline
\end{tabular}




\section{İ. Çevik Tekin - T. Akgemci 11/3 (2019) 1674-1692}

\subsection{Yenilikçi İş Davranışı Ölçeği Açımlayıcı Faktör Analizi}

Yenilikçi iş davranışı ölçeğinin güvenirliğini ölçmek için Cronbach Alfa güvenirlik katsayısı kullanılmıştır. Faktör analizi yapılmadan önce ölçek verilerinin faktör analizine uygunluğunu belirlemek amacıyla "KaiserMeyer-Olkin (KMO) katsayısı" ve "Bartlett Küresellik Testi" hesaplanmıştır. Yenilikçi iş davranışı ölçeğinin yapı geçerliliğini belirlemek için açımlayıcı faktör analizi kullanılmıştır. Yenilikçi İş Davranışı Ölçeğinin güvenirliği Cronbach Alpha güvenirlik katsayısı hesaplanarak incelenmiştir. Cronbach Alpha katsayısı 0-1 arasında değişmekte olup, değerlendirme kriterlerine göre; “ $0.00 \leq \alpha<0.40$ ise ölçek güvenilir değil, $0.40 \leq \alpha$ $<0.60$ ise ölçek düşük güvenirlikte, $0.60 \leq \alpha<0.80$ ise ölçek oldukça güvenilir ve $0.80 \leq \alpha<1.00$ ise ölçek yüksek derecede güvenilir" olarak değerlendirilmektedir (Tavşancıl, 2014: 29). Yenilikçi iş davranışı ölçeğinin Cronbach Alpha değeri 0,81 olarak hesaplanmıştır. Hesaplanan bu katsayılar ölçeğin iç tutarlılığa bağlı güvenirliğinin yeterli olduğuna işaret etmiştir. Ölçeğe serbest faktör sayısı ile uygulanan açımlayıcı faktör analizi uygulamasında ölçeğin 2 faktörlü bir yapıya eğilimli olduğu görülmüştür. Ölçeğin tasarımında 4 faktörlü yapıya sahip olması sebebiyle ölçek 4 faktöre zorlanarak tekrar faktör analizine tabi tutulduğunda ortaya çıkan faktör yapısının ölçeğin tasarımındaki ölçek yapısı ile içerik olarak örtüşmediği görülmüştür. Söz konusu sorunun çözümlenmesi için ölçeğin serbest faktör sayısı ile yapılan faktör analizi bulguları incelendiğinde iki faktöre ait maddelerin birbiri ile yüksek derecede korelasyon ilişkisine sahip olduğu ve dolayısıyla birlikte faktör oluşturdukları gözlemlenmiştir. Bu durumda söz konusu faktörlerin birleştirilerek kompozit değişken oluşturulmasına karar verilmiştir. Faktör analizinin gerçekleştirilebilmesi için, örneklem sayısının yeterli olması ve veri setinin faktör analizine uygun olması gerekmektedir. Bu durumun tespiti ile ilgili KMO değeri hesaplanarak ve Barttlet Küresellik Testi ile söz konusu varsayımlar kontrol edilmiştir. Bu ölçütle ilgili Kaiser (1974) 0,5 oranını hemen hemen kabul edilebilir bir kesim noktası olarak ifade etmiş ve KMO değerini 0,5-07 arası orta, 0,7-0,8 arası iyi, 0,8-0,9 arası çok iyi ve 0,9 üzerini mükemmel olarak sınıflandırmıştır. KMO değeri 0,83 olarak hesaplanmıştır. Kaiser (1974)'e göre KMO değerinin 0,70'den yüksek olması faktör analizi için örneklem büyüklügünün yeterli olduğunu göstermektedir. Bartlett küresellik testi ise ölçek maddelerinin birbiriyle ilişkisi hakkında bilgi verir ayrıca ölçeğin tek boyutlu ya da alt boyutlara sahip olup olmadığı tespit eder. Bartlett küresellik testinde $\mathrm{p}<0.05$ olması istenir. Bu durumda ölçek maddelerinin birbirleriyle uyumlu olduğu düşünülür. $p>0.05$ ise maddelerin birbirlerinden bağımsız oldukları ya da yeterli korelasyon düzeyinde olmadıkları anlamına gelir. (Can, 2013; Özdamar, 2016 ). Bartlett Küresellik testi sonuçlarına göre, ölçek maddeleri birbirleriyle yeterli korelasyon ilişkisi içerisindedir. Ayrıca ölçek maddeleri, ölçmeyi istediği olguyu ölçmede etkindir.

AFA sonucunda, öz-değeri 1'den büyük 2 faktörün oluştuğu görülmüştür. Ayrıca, yamaç serpinti grafiğinde ikinci faktörden sonra eğimin bir plato oluşturduğu anlaşılmıştır. Üçüncü ve sonraki faktörlerin özdeğerlerinin birbirine oldukça yakın olduğu ve bu faktörlerin toplam varyansa katkılarının sınırlı düzeyde bulunduğu belirlenmiştir. Bu bilgiler ışığında ölçeğin iki faktörlü olmasına karar verilmiş ve ölçek maddeleri 2 faktöre zorlanarak açımlayıcı faktör analizi uygulanmıştır. Ölçek maddelerinin ait olduğu faktörü belirgin hale getirmek için Varimax (maksimum değişkenlik) yöntemi kullanılarak döndürme işlemi gerçekleştirilmiştir. Faktör analizi sonucunda ölçekte binişik madde veya maddelerin bulunmadığı gözlenmiştir. Yenilikçi İş Davranışı Ölçeğinin faktör yapısı Tablo 3'de yer almaktadır. 
Tablo 3. Yenilikçi İş Davranışı Ölçeğinin Açımlayıcı Faktör Analizi Sonucu Elde Edilen Faktör Yapısı

\begin{tabular}{|c|c|c|c|c|c|}
\hline \multirow[b]{3}{*}{ Maddeler } & \multicolumn{2}{|c|}{ Faktörler } & \multirow[b]{3}{*}{ 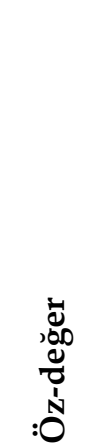 } & \multirow[b]{3}{*}{ 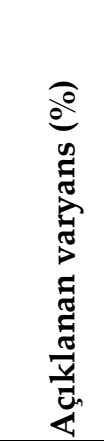 } & \multirow[b]{3}{*}{$\begin{array}{l}\frac{\pi}{2} \\
\frac{1}{2} \\
0 \\
0 \\
\frac{1}{0} \\
0 \\
0 \\
0 \\
0 \\
0\end{array}$} \\
\hline & 1 & 2 & & & \\
\hline & 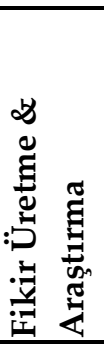 & 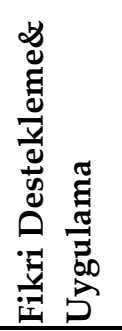 & & & \\
\hline 4. Sorunlara farklı çözümler geliştiririm & 0,84 & & & & \\
\hline 2. İşlerin nasıl geliştiğini merak ederim & 0,80 & & & & \\
\hline 5. İş yürütme konusunda yeni yaklaşımlar ortaya koyarım. & 0,78 & & 386 & 38.58 & 0.84 \\
\hline 1. Kendi işim dışındaki sorunlara önem veririm & 0,76 & & 3,86 & 38,58 & 0,84 \\
\hline $\begin{array}{l}\text { 3. Yeni iş metotları, teknikleri ya da araç-gereçlerini araştırıp } \\
\text { öğrenirim }\end{array}$ & 0,62 & & & & \\
\hline 6. Önemli örgüt üyelerini yenilikçi fikirler için motive ederim & & 0,81 & & & \\
\hline 7. İnsanları yenilikçi fikirleri desteklemeleri için ikna ederim & & 0,79 & & & \\
\hline 9. Yeni fikirlerin uygulanmasına katkıda bulunurum & & 0,72 & 2,06 & 0,58 & 0,80 \\
\hline 10. Yeni işlerin geliştirilmesine çaba harcarım. & & 0,71 & 2,00 & 0, & 0,00 \\
\hline $\begin{array}{l}\text { 8. İşin uygulanabilmesi için sistematik olarak yenilikçi fikirler } \\
\text { ortaya koyarım }\end{array}$ & & 0,66 & & & \\
\hline
\end{tabular}

Ölçeğin teorik yapısı ile faktör analizi bulgularının örtüşmesi ise faktör analizi bulgularının güvenirliliğini artırmaktadır. Faktör analizi aşamalarından sonra elde edilen altboyut yapısı ile ölçeklere Cronbach Alpha güvenirlilik analizi uygulanmıştır. Faktör analizi sonucunda birinci ve ikinci faktörlerin her birinde 5 maddenin bulunduğu anlaşılmaktadır. Ölçeğin özgün yapısında belirtilen fikir üretme ve fikir araştırma maddelerinin birinci faktörde; fikri destekleme ve fikri uygulama maddelerinin ise ikinci faktörde toplandığ1 gözlenmiştir. Ölçeğin birinci ve ikinci faktörlerinde bulunan maddelerin faktör yükleri sırasıyla 0,62-0,84 ve 0,66-0,81 arasında değerler almıştır. Ölçek ve faktör güvenirlilikleri incelendiğinde ise fikir üretme \& araştırma faktörü, fikri destekleme \& uygulama ve yenilikçi davranış ölçeğinin çok iyi düzeyde güvenilir ölçekler oldukları görülmüştür. Bu araştırmada, ölçeğin; fikir üretme \& araştırma ve fikri destekleme \& uygulama faktörlerine ait Alfa katsayıları sırasıyla 0,84 ve 0,80 olarak hesaplanmıştır. Hesaplanan katsayılar ölçeğin iç tutarlılığa bağlı güvenirliğinin yeterli düzeyde olduğunu göstermiştir.

Yenilikçi iş davranışını faktör analizleri neticesinde iki faktörde ele alan araştırmacılar olmuştur. Örneğin, Dorenbosch vd. (2005) yenilikçi davranışı yaratıcı odaklı iş davranışı ve uygulama odaklı iş davranışı olarak ele almışlardır. Krause (2004) ise ilk faktörü, "fikirlerin üretilmesi ve test edilmesi" olarak, ikinci faktörü ise "uygulama" olarak kullanmıştır. Faktörler tarafından açıklanan varyans oranları ise şu şekildedir; ilk faktör tek başına ölçek varyansının yaklaşık \%39'unu, ikinci faktör yaklaşık \%21'ini iki faktör birlikte yaklaşık \%60'ını açıklayabilmektedir. Krause (2004) çalışmasında da iki faktör toplam varyansın yaklaşık \%61'ini açıklamaktadır. Açıklanan varyans oranının \%50'inin üzerinde olması da ölçeğin iki faktörlü yapısının ideal yapı olduğu konusundaki bir başka bulgu olarak nitelendirilebilir. Özkan (2017) çalışanların özyeterlilik algılarının yaratıcı ve yenilikçi iş davranışlara etkisini ölçtüğü çalışmasında De Jong ve Den Hartog (2010) tarafından geliştirilen Yenilikçi İş Davranışları Ölçeğini kullanmıştır. Ölçek faktörlerini ise, "yaratıcı iş davranışları" ve "yenilikçi iş davranışları" olarak ele almıştır.

\subsection{Psikolojik Güçlendirme Ölçeği Açımlayıcı Faktör Analizi}

Psikolojik Güçlendirme Ölçeğinin güvenirliği Cronbach Alpha güvenirlik katsayısı hesaplanarak incelenmiştir. Likert tipi bir ölçekte güvenirlik düzeyini belirlemek için iç tutarlılık ölçütü olarak kabul edilen Cronbach Alpha $(\alpha)$ katsayısının kullanılması uygundur. Bu katsayı, 0 ile 1 arasında değer almaktadır ve değer 1'e yaklaştıkça ise ölçek maddelerin birbiriyle tutarlı ve aynı özelliğe sahip öğeleri ölçmekte oldukları göstermektedir (Tezbaşaran, 1996: 46). Ölçek güvenirliğinin yeterli düzeyde kabul edilebilmesi için Cronbach 


\section{İ. Çevik Tekin - T. Akgemci 11/3 (2019) 1674-1692}

Alpha katsayısının 0,70 ve üzerinde olması gerekmektedir. Bu kriterin karşılanamadığı durumda, iç tutarlılığa bağlı güvenirliğin yeterli düzeyde olmadığı yönünde yorum yapılmaktadır (Tavşancıl, 2014). Psikolojik güçlendirme ölçeğinden elde edilen $\alpha$ katsayı 0,80 olarak hesaplanıp, ölçeğin iç tutarlılığa bağlı güvenirliğinin yeterli düzeyde olduğunu işaret etmiştir.

KMO değerinin 0,79 olarak hesaplandığı görülmektedir. Bu değerin 0,70 ve üzerinde olması örneklem sayısının faktör analizi için yeterli olduğunu göstermektedir (Kaiser, 1974). Bartlett Küresellik Testinin kullanılma amacı ise veri setinin faktör analizine uygun olup olmadığını belirlemektir. Bartlett küresellik testi ise ölçek maddelerinin birbiriyle ilişkisi hakkında bilgi verir ayrıca ölçeğin tek boyutlu ya da alt boyutlara sahip olup olmadığı tespit eder. Bartlett küresellik testinde $\mathrm{p}<0.05$ olması istenir. Bu durumda ölçek maddelerinin birbirleriyle uyumlu olduğu düşünülür. $p>0.05$ ise maddelerin birbirlerinden bağımsız oldukları ya da yeterli korelasyon düzeyinde olmadıkları anlamına gelir. (Can, 2013; Özdamar, 2016). Neticede, KMO Küresellik Testi sonucunda hesaplanan KMO değeri ile örneklem sayısının faktör analizi için yeterli olduğu, Bartlett Küresellik Testi sonucu elde edilen $p$ anlamlılık değeri ile de verilerin faktör analizine uygun olduğu tespit edilmiştir.

Ölçeğe serbest faktör sayısı ile uygulanan açıklayıcı faktör analizi uygulamasında ölçeğin 3 faktörlü bir yapı ortaya koyduğu görülmüştür. Ölçeğin tasarımında 4 faktörlü yapıya sahip olduğu bilindiğinden ölçek 4 faktöre zorlanarak faktör analizi tekrarlanmıştır. 4 faktörlü yapı incelendiğinde ortaya çıkan faktör yapısının içerik olarak ideal olmadığı gözlemlenmiştir. Ölçeğin serbest faktör sayısı ile yapılan faktör analizi bulguları incelendiğinde iki faktörün birleşerek kompozit bir değişken oluşturduğu gözlemlenmiştir. Yamaç serpinti grafiği incelendiğinde üçüncü faktörden sonra eğimin bir plato oluşturduğu anlaşılmıştır. Dördüncü ve sonraki faktörlerin öz-değerlerinin birbirine oldukça yakın olduğu ve bu faktörlerin toplam varyansa katkılarının sınırlı düzeyde bulunduğu belirlenmiştir. Bu bilgiler ışığında ölçeğin üç faktörlü olup, söz konusu iki faktörün birleştirilerek kompozit değişken olarak kullanılmasına karar verilmiştir. Faktör analizi sonucunda birinci faktörde 6, ikinci ve üçüncü faktörde ise 3'er maddenin bulunduğu anlaşllmaktadır. Özgün ölçekte belirtilen özerklik ve etki maddelerinin birinci faktörde toplandığı anlaşılmıştır. Özerklik \& etki, anlam ve yeterlik faktörlerinde bulunan maddelere ait faktör yüklerinin sırasıyla 0,55-0,76; 0,72-0,92 ve 0,74-0,82 arasında değişen değerler aldığı gözlenmiştir. Psikolojik Güçlendirme Ölçeğinin güvenirliği Cronba Alfa güvenirlik katsayısı hesaplanarak incelenmiştir. Bu araştırmada, ölçeğin özerklik \& etki, anlam ve yeterlik faktörlerine ait Alfa katsayıları sırasıyla 0,76; 0,85 ve 0,71 olarak hesaplanmıştır. Elde edilen katsayılar ölçeğin iç tutarlılığa bağlı güvenirliğinin yeterli düzeyde olduğunu işaret etmiştir.

Spreitzer $(1995,1996)$ psikolojik güçlendirme ölçeğini 4 faktörde kullanmalarına rağmen literatürde, bu çalışma da olduğu gibi, ölçek maddelerinin üç faktörde dağıldığı çalışmalar mevcuttur. Bu çalışmalardan bahsetmek gerekirse; Çavuş (2008), çalışmasında anlam ve yetenek boyutları tek bir faktör olarak ele alarak anlam-yetenek, özerklik ve etki olarak toplam üç faktör kullanmıştır. Toplu ve Akça (2013) çalışmasında, anlam, yetkinlik kendi boyutlarında toplanmışken özerklik ve etki boyutları birleşerek tek faktör altında toplanmıştır. Çalışmada boyutları, anlam, yetkilik ve özerklik-etki olarak kullanılmıştır. Hemedoğlu ve çalışma arkadaşları 2012 yılında yaptıkları çalışmada söz konusu ölçeği etki, yetkinlik ve anlam boyutları olmak üzere üç faktörde kullanmışlardır. Çalışmada, etki boyutu Spreitzer (1995) ölçeğindeki gibidir; etkinlik boyutu 4 ifadeden ( 1 ifade anlam boyutundan), anlam boyutu ise 2 ifadeden oluşmaktadır. Fulford ve Enz (1995) psikolojik güçlendirmenin boyutlarını anlam, yeterlilik ve etki olarak ölçeklendirmişlerdir. Çöl (2008) yapmış olduğu çalışmada, anlam ve yetkinlik boyutlarının tek faktörde yüklenmesi sonucu çalışma boyutlarını özerklik, etki ve anlam-yetkinlik olarak kullanmışlardır. 
Tablo 4. Psikolojik Güçlendirme Ölçeğinin Açımlayıcı Faktör Analizi Sonucu Elde Edilen Faktör Yapısı

\begin{tabular}{|c|c|c|c|c|c|c|}
\hline \multirow[b]{3}{*}{ Maddeler } & \multicolumn{3}{|c|}{ Faktörler } & \multirow[b]{3}{*}{ 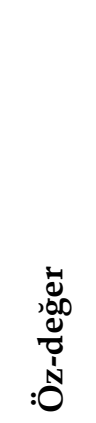 } & \multirow{3}{*}{ 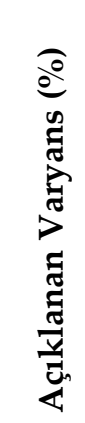 } & \multirow[b]{3}{*}{ 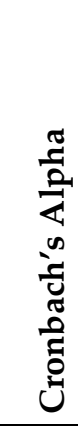 } \\
\hline & 1 & 2 & 3 & & & \\
\hline & 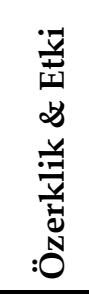 & 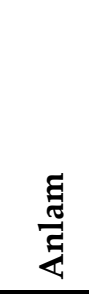 & 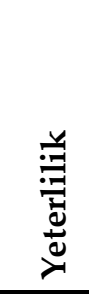 & & & \\
\hline 10. Bölümümde olup bitenler üzerinde büyük etkim vardır & 0,76 & & & & & \\
\hline $\begin{array}{l}\text { 11. Bölümümdeki olaylar üzerindeki kontrolüm } \\
\text { oldukça fazladır }\end{array}$ & 0,72 & & & & & \\
\hline $\begin{array}{l}\text { 12. Bölümümdeki olaylar üzerindeki nüfuzum oldukça } \\
\text { fazladır. }\end{array}$ & 0,72 & & & & & \\
\hline $\begin{array}{l}\text { 7. İşimi nasıl yapacağımı belirlemede önemli ölçüde } \\
\text { özerkliğe sahibim. }\end{array}$ & 0,62 & & & 3,98 & 33,2 & 0,76 \\
\hline $\begin{array}{l}\text { 9. İşimi nasıl yapacă̆ım konusunda seçim yapmakta } \\
\text { bağımsız ve özgürüm. }\end{array}$ & 0,62 & & & & & \\
\hline $\begin{array}{l}\text { 8. İşimi nasıl yürüteceğime dair kararları kendim } \\
\text { verebiliyorum. }\end{array}$ & 0,55 & & & & & \\
\hline $\begin{array}{l}\text { 2. İşimle ilgili yaptığım faaliyetler bana anlamlı } \\
\text { gelmektedir. }\end{array}$ & & 0,92 & & & & \\
\hline 1. Yaptığım iş benim için çok önemlidir. & & 0,92 & & 2,06 & 17,2 & 0,85 \\
\hline 3. Yaptığım iş benim için anlamlıdır. & & 0,72 & & & & \\
\hline $\begin{array}{l}\text { 6. İşim için gereken becerilerde uzmanlık seviyesinde } \\
\text { sahibim. }\end{array}$ & & & 0,82 & & & \\
\hline 5. İşimi yapmak için gereken kapasiteye sahibim. & & & 0,74 & 1,36 & 11,4 & 0,71 \\
\hline $\begin{array}{l}\text { 4. İşimi yapmak için gereken yeteneklere sahip } \\
\text { olduğuma eminim. }\end{array}$ & & & 0,74 & & & \\
\hline
\end{tabular}

Faktör analizi sonucunda birinci faktörde 6, ikinci ve üçüncü faktörde ise 3'er maddenin bulunduğu görülmektedir. Özgün ölçekte belirtilen özerklik \& etki maddelerinin birinci faktörde toplandığı anlaşılmıştır. Özerklik \& etki, anlam ve yeterlilik faktörlerinde bulunan maddelere ait faktör yüklerinin sırasıyla 0,55-0,76; 0,72-0,92 ve 0,74-0,82 arasında değişen değerler aldığı gözlenmiştir. Psikolojik Güçlendirme Ölçeğinin güvenirliği Cronbach Alfa güvenirlik katsayısı hesaplanarak incelenmiştir. Alfa katsayısının 0,70 ve üzerinde olması gerekmektedir. Bu kriterin karşılanamadığı durumda, iç tutarlılığa bağlı güvenirliğin yeterli düzeyde olmadığı yönünde yorum yapılmaktadır (Tavşancıl, 2014). Bu araştırmada, ölçeğin özerklik \& etki, anlam ve yeterlik faktörlerine ait Alfa katsayıları sırasıyla 0,76; 0,85 ve 0,71 olarak hesaplanmıştır. Hesaplanan bu katsayılar ölçeğin iç tutarlılı̆̆a bağlı güvenirliğinin yeterli düzeyde olduğunu işaret etmiştir.

\subsection{Faktör Analizi Neticesinde Oluşan Araştırmanın Modeli ve Hipotezleri}

Çalışmada, psikolojik güçlendirmenin yenilikçi iş davranışı üzerindeki etkisi incelenecektir. Bu nedenle çalışma kapsamında psikolojik güçlendirme bağımsız değişken, yenilikçi iş davranışı ise bağımlı değişken olarak kullanılmıştır. Faktör analizi sonrasında ortaya çıkan faktör yapısı neticesinde araştırmanın modeli Şekil 2'deki gibi oluşturulup, aşağıdaki hipotez ileri sürülmüştür. 


\begin{tabular}{|c|}
\hline Psikolojik Güçlendirme \\
Özerklik-Etki \\
Anlam \\
Yeterlilik \\
\hline
\end{tabular}

Bağımsız Değişken

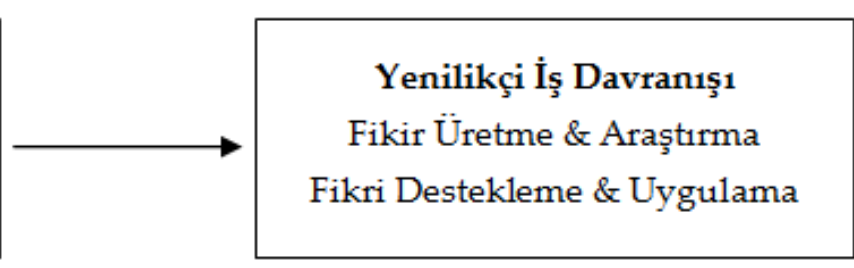

Bağımlı Değişken

Şekil 2. Araştırmanın Modeli

H: Psikolojik güçlendirmenin yenilikçi iş davranışı üzerinde olumlu etkisi vardır.

H.1: Anlam değişkeninin fikir üretme \& araştırma üzerinde olumlu etkisi vardır.

H.2: Yeterlilik değişkeninin fikir üretme \& araştırma üzerinde olumlu etkisi vardır.

H.s: Özerklik \& etki değişkeninin fikir üretme \& araştırma üzerinde olumlu etkisi vardır.

H.4: Anlam değişkeninin fikir destekleme \& uygulama üzerinde olumlu etkisi vardır.

H.s: Yeterlilik değişkeninin fikir destekleme \& uygulama üzerinde olumlu etkisi vardır.

H.6: Özerklik \& etki değişkeninin fikir destekleme \& uygulama üzerinde olumlu etkisi vardır.

Tablo 5. Korelasyon Tablosu

\begin{tabular}{|c|c|c|c|c|c|c|c|c|}
\hline & Değişkenler & 1 & 2 & 3 & 4 & 5 & 6 & 7 \\
\hline 1 & Fikir Üretme \& Araştırma & 1 & & & & & & \\
\hline 2 & $\begin{array}{l}\text { Fikri Destekleme \& } \\
\text { Uygulama }\end{array}$ &, $317^{* *}$ & 1 & & & & & \\
\hline 3 & Yenilikçi İş davranışı &, $855^{* *}$ &, $762^{* *}$ & 1 & & & & \\
\hline 4 & Anlam & $449^{* *}$ &, $531^{* *}$ &, $597^{* *}$ & 1 & & & \\
\hline 5 & Yeterlilik & $146^{* *}$ & $280^{* *}$ & $252^{* *}$ & $130^{* *}$ & 1 & & \\
\hline 6 & Özerklik \& Etki & $273^{* *}$ & $650^{* *}$ &, $541^{* *}$ &, $372^{* *}$ &, $365^{* *}$ & 1 & \\
\hline 7 & Psikolojik Güçlendirme &, $422^{* *}$ &, $708^{* *}$ &, $675^{* *}$ &, $759 * *$ &, $538^{* *}$ &, $840^{* *}$ & 1 \\
\hline
\end{tabular}

Korelasyon tablosunda, değişkenler arasında düşük ve orta düzeyde pozitif yönlü ve istatistiksel olarak anlamlı ilişkiler bulunmaktadır. Kesin sınırlamalar olmamakla beraber 0,50'nin altında korelasyon zayıf; 0,50-0,70 arasında korelasyon orta, 0,70'in üzerindeki korelasyon ise güçlü korelasyonu göstermektedir (Durmuş vd., 2013: 145). Katılımcıların psikolojik güçlendirme ve psikolojik güçlendirme ile ilişkili anlam, yeterlilik ve özerklik \& etki puanları arttıkça yenilikçi davranış ve yenilikçi iş davranış ile ilişikli fikir üretme \& araştırma ve fikri destekleme \& uygulama puanları da artış göstermektedir. Söz konusu değişkenler arasında pozitif yönlü korelasyonlar mevcuttur. Araştırma hipotezini test etmek için Şekil 2'de yer alan model geliştirilmiş ve test edilmiştir. Modelde anlam, yeterlilik, özerklik \& etki değişkenleri bağımsız değişken; fikir üretme \& araştırma ve fikri destekleme \& uygulama değişkenleri ise bağımlı değişken olarak kullanılmaktadır. Modelin test edilmesi ile elde edilen uyum değerleri; modelin veriler ile iyi düzeyde uyum gösterdiğini göstermektedir (Tablo 6).

Tablo 6. Psikolojik Güçlendirme Boyutlarının Yenilikçi İş Davranışı Boyutları Üzerindeki Etkisini Belirlemek İçin Test Edilen Yapısal Eşitlik Modeline Ait Uyum Değerleri

\begin{tabular}{ccccccc}
\hline$\chi^{2} / \mathbf{s d}$ & GFI & AGFI & CFI & RMSEA & SRMR & TLI \\
\hline 1,26 & 1,00 & 0,98 & 1,00 & 0,03 & 0,02 & 1,00 \\
\hline
\end{tabular}




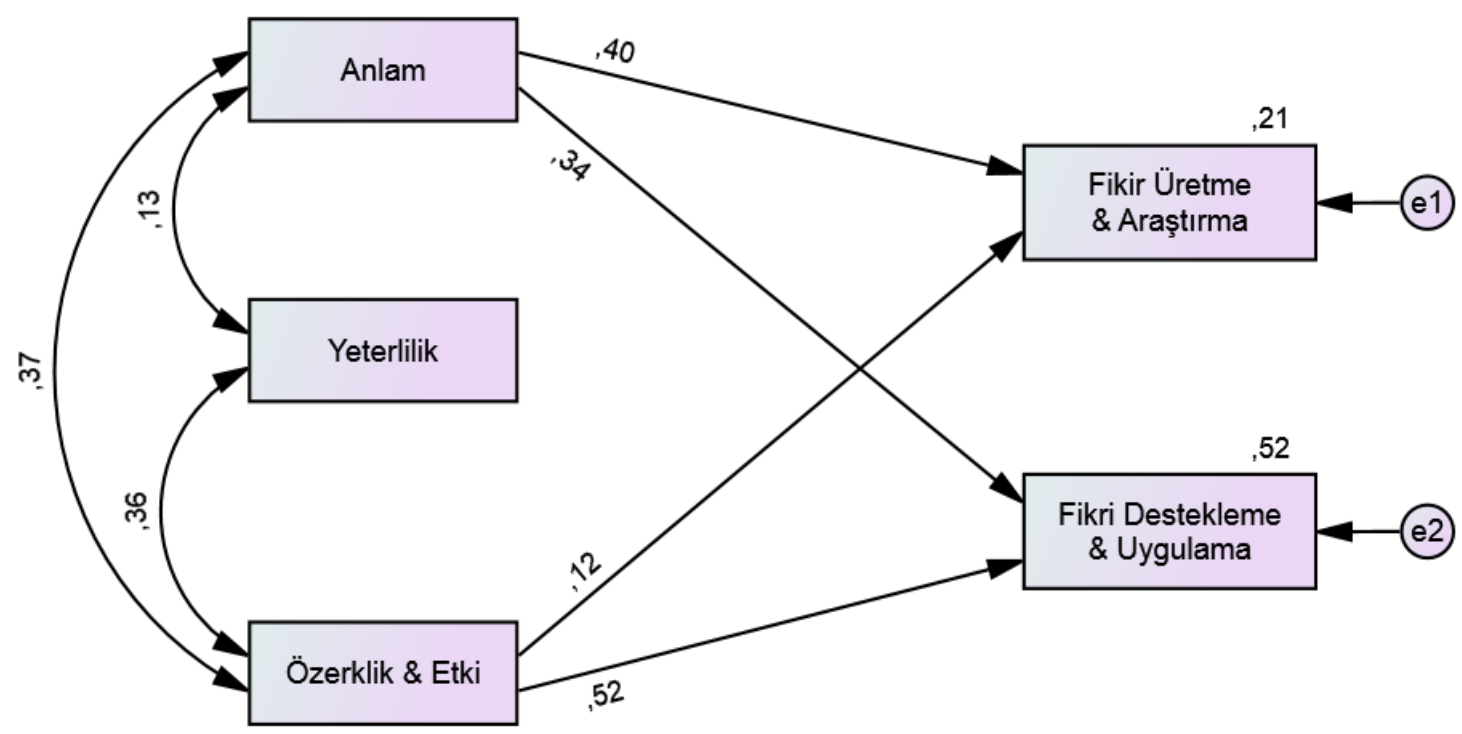

Şekil 2. Psikolojik Güçlendirme Boyutlarının Yenilikçi İş Davranışı Boyutları Üzerindeki Etkisini Belirlemek İçin Test Edilen Yapısal Eşitlik Modeli

Modelde yer alan ve istatistiksel olarak anlamlı bulunan yol katsayıları incelendiğinde; anlam değişkeninin fikir üretme \& araştırma $(\beta=0,40 ; p<0,001)$ ve fikri destekleme \& uygulama $(\beta=0,34 ; p<0,001)$ pozitif yönde etkilediği anlaşılmaktadır. Bu durumda araştırmanın $\mathrm{H}_{1}$ ve $\mathrm{H}_{4}$ hipotezleri kabul edilmiştir

Yeterlilik değişkeninin yenilikçi davranış boyutları üzerinde herhangi bir anlamlı etkisi bulunmamaktadır. Buna göre araştırmanın $\mathrm{H}_{2}$ ve $\mathrm{H}_{5}$ hipotezleri reddedilmiştir. Son olarak, özerklik \& etki değişkeninin fikir üretme \& araştırma $(\beta=0,12 ; p<0,05)$ ve fikri destekleme \& uygulamayı $(\beta=0,52 ; p<0,001)$ pozitif yönde etkilediği belirlenmiştir. Buna göre araştırmanın $\mathrm{H}_{3}$ ve $\mathrm{H}_{6}$ hipotezleri kabul edilmiştir.

Fikir üretme \& araştırmaya etki eden anlam ve özerklik \& etki değişkenlerinin fikir üretme \& araştırmadaki değişimin yaklaşık \%21'ini açıkladığı belirlenmiştir. Fikri destekleme \& uygulamaya etki eden anlam ve özerklik \& etki değişkenlerinin fikri destekleme \& uygulamadaki değişimin yaklaşık \%52'sini açıladığı belirlenmiştir. Anlam ve özerklik \& etki değişkenlerinin fikri destekleme \& uygulamaya değişkeni üzerinde önemli bir etkiye sahip olduğu belirlenmiştir.

Araştırmada oluşan regresyon denklemleri şu şekildedir;

Fikir üretme \& araştırma $=(0,40) *$ Anlam $+(0,12) *$ Özerklik \& Etki + Sabit

Fikri destekleme \& uygulama $=(0,34) *$ Anlam $+(0,52){ }^{*}$ Özerklik \& Etki + Sabit

Tablo 7. Psikolojik Güçlendirme Boyutlarının Yenilikçi İş Davranışı Boyutları Üzerindeki Etkisini Belirlemek İçin Hesaplanan Yol Katsayıları

\begin{tabular}{|c|c|c|c|c|c|c|c|}
\hline Bağımlı Değişken & & $\begin{array}{l}\text { Bağımsız } \\
\text { Değişken }\end{array}$ & B & S. H. & B & K.O. & $\mathbf{P}$ \\
\hline $\begin{array}{l}\text { Fikir Üretme \& } \\
\text { Araştırma }\end{array}$ & $<---$ & Anlam & 0,564 & 0,066 & 0,404 & 8,53 & $* * *$ \\
\hline $\begin{array}{l}\text { Fikri Destekleme \& } \\
\text { Uygulama }\end{array}$ & $<---$ & Özerklik \& Etki & 0,536 & 0,042 & 0,521 & 12,823 & $* * *$ \\
\hline $\begin{array}{l}\text { Fikri Destekleme \& } \\
\text { Uygulama }\end{array}$ & $<---$ & Anlam & 0,375 & 0,041 & 0,336 & 9,081 & $* * *$ \\
\hline $\begin{array}{l}\text { Fikri Destekleme \& } \\
\text { Uygulama }\end{array}$ & $<--$ & Yeterlilik & 0,111 & 0,079 & 0,051 & 1,395 & 0,163 \\
\hline $\begin{array}{l}\text { Fikir Üretme \& } \\
\text { Araştırma }\end{array}$ & $<---$ & Özerklik \& Etki & 0,135 & 0,067 & 0,122 & 2,023 & 0,043 \\
\hline $\begin{array}{l}\text { Fikir Üretme \& } \\
\text { Araştırma }\end{array}$ & $<--$ & Yeterlilik & 0,15 & 0,127 & 0,056 & 1,183 & 0,237 \\
\hline
\end{tabular}


Tablo 8. Hipotez Özeti Tablosu

\begin{tabular}{lll} 
& $\mathrm{H}_{1}$ & Doğrulandı \\
& $\mathrm{H}_{2}$ Doğrulanmadı \\
H: Psikolojik güçlendirmenin yenilikçi iş davranışı üzerinde olumlu etkisi & $\mathrm{H}_{3}$ Doğrulandı \\
vardır. & $\mathrm{H}_{4}$ Doğruland 1 \\
& $\mathrm{H}_{5}$ Doğrulanmadı \\
& $\mathrm{H}_{6} \quad$ Doğruland 1 \\
\hline
\end{tabular}

\section{Sonuç, Tartışma ve Öneriler}

Araştırmanın hipotezlerine ait bulgular değerlendirildiğinde psikolojik güçlendirmenin boyutları, fikri destekleme \& uygulama boyutuna \%50'nin üzerinde etki sağlamaktadır. Çalışanların psikolojik güçlendirme sayesinde, yenilikçi iş davranışının yaratıcılık boyutundan daha çok uygulama boyutuna katkılarının daha yüksek olduğu söylenebilir. Çalışanlarda psikolojik güçlendirmenin yenilikçi iş davranışına genel olarak pozitif etkisinin olduğu görülmüştür. Ancak psikolojik güçlendirmenin yeterlilik boyutunun yenilikçi iş davranışının hiçbir boyutuna etkisinin olmaması araştırmanın önemli bulgularındandır. Thomas ve Velthouse (1990)'a göre, çalışanın yeterliliğine ilişkin tereddütleri varsa ya da çalışan düşük özgüvene sahipse yeteneklerini kullanmayı gerektirecek durumlardan kaçınacaktır. Redmond ve çalışma arkadaşları 1993 yılında yaptıkları çalışmada özyeterliliği yüksek ve işi benimsemiş çalışanların daha fazla yenilikçi davranış sergileyeceklerini belirtmişlerdir. Çekmecelioğlu ve Eren 2007 yılında psikolojik güçlendirmenin boyutlarının yaratıcı davranış üzerindeki etkisini inceledikleri modelde yeterlilik boyutunun yaratıcı davranış üzerinde herhangi bir etkisinin olmadığını bulgulamışladır. Özkan (2017), De Jong ve Den Hartog (2010) tarafından geliştirilen Yenilikçi İş Davranışları Ölçeğini kullandığı çalışmasında ölçek faktörlerini, "yaratıcı iş davranışları" ve "yenilikçi iş davranışları" olarak ele almıştır. Çalışma sonucu, özyeterliliğin hem yaratıcı hem de yenilikçi iş davranışlarını pozitif yönde etkilediğini bulgulamıştır. Örücü ve Çınar (2019), pozitif psikolojik sermayenin yenilikçi iş davranışı üzerinde etkisini araştırdıkları çalışmalarında psikolojik sermayenin alt boyutlarından olan özyeterlilik boyutu ile tek boyutta ele aldıkları yenilikçi iş davranışı arasında anlamlı bir ilişkiye rastlamamışlardır. Genel olarak, çalışanların yaptıkları işlerle ilgili yeteneklerine güvenmeleri, yenilikçi iş davranışlarını gerçekleştirmeleri için yeterli olmamaktadır. Psikolojik güçlendirmenin gerçekleşmesi için çalışanlar işlerini anlamlı bulup, işin süreçlerine ve sonuçlarına etki edip işle ilgili karar alımlarına katılmaları gerekmektedir.

Çalışanların yaptıkları işleri anlamlı bulmaları, yenilikçi iş davranışları ile ilgili hem fikir üretme \& araştırma boyutuna hem de fikir destekleme \& uygulama boyutuna pozitif etki etmektedir. Ancak yaratıcı davranışlarla ilgili olan fikir üretme \& araştırma boyutuna etkisi daha yüksektir $(0,40>0,34)$. Bu durum örgütsel davranış açısından istenilen bir durumdur. Çoğu zaman yenilikçi iş davranışlarını başlatmak bu davranışları devam ettirmekten daha zordur ve yaratıcılık gerektirir. Çekmecelioğlu ve Eren (2007) yapmış oldukları çalışmada psikolojik güçlendirmenin boyutları olan anlam, otonomi, etkinin yaratıcı davranışları (fikir üretme \& araştırma) pozitif yönde etkilediğini bulgulamışlardır. Ayrıca anlam ve yeterliliğin yaratıcı davranış üzerindeki etkisinin incelendiği diğer bir regresyon modelinde her iki değişkeninde yaratıcı davranışları olumlu yönde etkilediğini ancak anlam boyutunun yaratıcı davranış üzerindeki etkisinin çok daha güçlü olduğunu $(0.21>0.18)$ bulgulamışlardır. Yenilikçi fikirleri başlatması istenilen çalışanların, anlam boyutu ile ilgili algılarının yükseltilmesi gerektiği açıktır.

Özerklik \& etki boyutu fikir üretme \& araştırma ve fikri destekleme \& uygulama boyutlarını pozitif yönde etkilemektedir. Ancak bu boyutun fikri destekleme \& uygulama boyutuna etkisi \%50'nin üzerindedir. Başka bir ifade ile çalışanların yerine getirdikleri işlerin süreçleri ve sonuçlar ile ilgili kararlar alabilmesi fikir üretme \& araştırma boyutundan ziyade fikir geliştirme \& uygulama boyutuna oldukça yüksek etki etmektedir. Spreitzer (1995) psikolojik güçlendirmenin boyutlarıyla yenilikçi davranışlar arasında pozitif ve anlamlı ilişkiler tespit etmiştir. Psikolojik güçlendirmenin gerçekleşmesi için ödüller, bilgi paylaşımı ve özsaygının gerekliliğinden bahsetmiştir. Çekmecelioğlu ve Eren (2007) psikolojik güçlendirmenin yaratıcı davranış üzerindeki etkisini incelendikleri regresyon modelinde anlam, otonomi ve etki boyutlarının yaratıcı davranışları (fikir üretme \& araştırma) pozitif olarak etkilediğini ve otonomi (özerklik) boyutunun yaratıcı davranışları en yüksek düzeyde etkileyen boyut olduğunu bulgulamışlardır $(\beta=0,22 ; p<0,005)$. Yaratıcı 


\section{İ. Çevik Tekin - T. Akgemci 11/3 (2019) 1674-1692}

davranışların ortaya çıkması ile yenilikçi iş davranışlarının, fikir üretme ve araştırma boyutlarının ilişkili olduğu (Oukes, 2010; Janssen, vd., 1997) bilindiğinden söz konusu çalışma bu araştırma kapsamında ele alınmıştır.

Tüm bu bulgulardan sonra uygulayıcılar için önerilerde bulunmak gerekirse,

- İnsan kaynakları yönetimi çalışan seçiminde; kendi duygularını tanıyan ve yönetebilen aynı zamanda empati kurabilen, alanında etkin ve verimli, ekip çalışması için uygun, yeni bilgiler öğrenmeye istekli adaylara öncelik vermelidirler. Yenilikçi olmayı işlerinin bir parçası olarak gören çalışanlar diğer çalışanlara göre; yenilikçi fikirler üretme, yenilikçi fikirleri benimseyip destekleme ve yenilikçi fikirlerin uygulama aşamalarına katkı sağlamada daha başarılı olacaklardır.

- Çalışanların örgütün stratejik hedeflerini bilmesi ve bu hedefleri gerçekleştirme sürecinde kendi rollerinin farkında olmaları sağlanmalıdır. Çalışanlar bu yönde cesaretlendirilip, bilgi, deneyim ve duygularını rahat bir şekilde ifade edebildikleri, karar aşamalarında inisiyatif kullanabildikleri ve istenmeyen durumlar oluştuğunda ise yönetim tarafından hoşgörü ortamının sağlandığı bir örgüt kültürü oluşturulmalıdır.

- Çalışanların örgüt içinde yenilikleri keşfedip piyasaya sunabilmesi için bilgi paylaşımına uygun, hiyerarşik yapıdan uzak örgütsel yapılar oluşturulmalıdır. Çünkü hiyerarşik örgütlerde, günlük sözlü iletişimden uzak, hiyerarşik basamaklara dayalı sözlü ya da yazılı iletişim kaynakları bulunmaktadır. Bu durum çalışanların yaratıcılıklarını göstermelerinin önünde bir engeldir.

- Yöneticilerin bu gerçekleri bilerek çalışanları güçlendirmeleri, özelikle çalışanların algıladıkları güçlendirmeyi (psikolojik güçlendirme) yüksek tutmaları gerektiği ortadadır. Kendisini etkili, bağımsız ve yetkin gören, ayrıca yaptığı işi anlamlı bulan çalışanın kendisini güçlendirilmiş hissedeceği açıktır. Çünkü yoğun rekabet şartlarının var olduğu küresel ortamlarda işlerini yerine getiren çalışanların algıladıkları psikolojik güçlendirmenin derecesi onların tutum ve davranışlarını etkileyecektir. Bu sayede ise çalışanların yenilikçi davranışlarının önü açılmış olacaktır.

Çalışma, otomotiv sektörü ile sınırlandırılmıştır. Belli bir zaman diliminde yapıldığından (Mart 2018-Aralık 2018) ve zaman içerisinde tutum ve algilar değişebileceğinden, bu çalışma gerçekleştirildiği süreç ile sınırlıdır. Ayrıca Türkiye'de otomotiv üretimi yapan firmalarda bu süreçte faaliyet gösteren beyaz yakalı Türk çalışanlar ile sınırlıdır. Bu nedenle, benzeri bir çalışma farklı sektör ve çalışanlarda uygulanabilir.

\section{Kaynakça}

Akkoç İ., (2012), "Gelişim Kültürü ve Etik İklimin Yenilikçiliğe Etkisinde Dağıtım Adaletinin Rolü", Uluslararası Alanya İşletme Fakültesi Dergisi, C:4, S:3, s. 45-60.

Barutçugil, İ. (2004). Stratejik İnsan Kaynakları Yönetimi. Kariyer Yayıncılık, Yayın No: 59, Yönetim Dizisi: 15, İstanbul.

Bass (1985) Model Of Transformational Leadership. In T.F. Mech \& G.B. Mccabe (Eds.), Leadership And Academic Librarians 66-82

Birkinshaw, J., Hamel, G., Mol, M.J. (2008). Management İnnovation. Academy of Management Review, 33(4), 825-845.

Cohen, L., Manion, L. and Morrison, K. (2000) Research Methods in Education. 5th Edition, Routledge Falmer, London.

Conger, J. A. (1989). Leadership: The Art Of Empowering Others. The Academy of Management Executive, 3 (1), 17-24.

Conger, J.A., Kanungo, R.N. (1988). The Empowerment Process: Integrating Theory And Practice. Academy Of Management Review, Vol. 13, No. 3, 55.471-482.

Cumming B.S. (1998). Innovation Overview And Future Challenges. European Journal Of Innovation Management, 1(1), 22. 


\section{İ. Çevik Tekin - T. Akgemci 11/3 (2019) 1674-1692}

Çavuş, D. M. F. (2008). Personel Güçlendirme: İmalat Sanayii İşletmelerinde Bir Araştırma. Journal of Yaşar University, 3(10), 1287-1300

Çavuş, F.M., Akgemci, T. (2008). İşletmelerde Personel Güçlendirmenin Örgütsel Yaratıcılık ve Yenilikçiliğe Etkisi: İmalat Sanayinde Bir Araştırma. Selçuk Üniversitesi Sosyal Bilimler Enstitüsü Dergisi, 20: 229-244.

Çekmecelioğlu, H.G., Özbağ, G.K. (2014). Linking Psychological Empowerment, Individual Creativity and Firm Innovativeness: A Research On Turkish Manufacturing Industry. Business Management Dynamics, 3(10), 01-13

Çekmecelioğlu, H. Ve Eren, E. (2007). Psikolojik güçlendirme, örgütsel bağlılık ve yaratıcı davranış arasındaki ilişkilerin değerlendirilmesi. Yönetim, 18(57), 13-25.

Çelik, M., Turunç, Ö., Bilgin, N. (2014). Lider-Üye Etkileşimi ve Kariyer Memnuniyetinin Yenilikçi Davranışa Etkisinde Etiğin Düzenleyici Rolüne Yönelik Deneysel Bir Araştırma. Mustafa Kemal Üniversitesi Sosyal Bilimler Enstitüsü Dergisi, 11(25), 491-508.

Çetin, M., Evcim, U. (2009). Örgütsel Kültürün Algılanmasında Metaforların Rolü. İletişim Kuram ve Araştırma Dergisi, 185-220.

De Jong, J. P., Den Hartog, D. N. (2008). Innovative work behaviour: Measurement and validation. EIM Business and Policy Research, 1-27.

De Jong, J., Den Hartog, D. (2010). Measuring innovative work behaviour. Creativity and Innovation Management, 19(1), 23-36.

Deci, E.L., Connell, J.P. Ryan, R.M. (1989). Self-Determination İn A Work Organization. Journal Of Applied Psychology, 74, 580-590.

Doğan, S. (2003). Personel Güçlendirme, İstanbul: Sistem Yayıncılık.

Doğan, S. (2006). Personel Güçlendirme Rekabette Başarının Anahtarı. İstanbul: Kare Yayınları, 2. Baskı.

Dorenbosch, L., Van Engen, M. L., Verhagen, M. (2005). On-The-Job Innovation: The İmpact of Job Design and Human Resource Management Through Production Ownership. Creativity And Innovation Management. 14(2). 129-141.

Durmuş, B., Yurtkoru, S., Çinko M., (2013). Sosyal Bilimlerde Spss'le Veri Analizi (5. Basım). İstanbul: Beta Yayınevi.

Durna U. (2002). Yenilik Yönetimi. Ankara: Nobel Yayınevi.

Fulford, M. D., Enz, C. A. (1995). "The Impact of Empowerment on Service Employees", Journal Of Managerial Issues, 7, 161-175.

Gümüşlüoğlu, L., Karakitapoğlu-Aygün, Z. (2010). The Effects of Perceived Justice And Empowerment On Organizational, Supervisory and Occupational Commitment: An Investigation On Knowledge Workers. Turkish Journal Of Psychology, 25(66), 21-36.

Gürbüz G. (2012). Personel Güçlendirme Uygulamalarının Örgütsel Bağhllı̆̆a Etkisi: Bankacılık Sektöründe Bir Araştırma. Trakya Üniversitesi, Sosyal Bilimler Enstitüsü, Yüksek Lisans Tezi, Edirne.

Hair, J., Black W., Babin B., Anderson R., Tahtam R. (2006). Multivariate Data Analysis (6.Basım). Usa: Pearson.

Hemedoğlu, E., Koçak, M., Özkan, A., Berberoğlugil, M. B. (2012). Psikolojik Güçlendirmenin Finansal Olmayan Performans Üzerindeki Etkileri. Eskişehir Osmangazi Üniversitesi Sosyal Bilimler Dergisi, 13(2): 87-105.

Holt, G.D., Love, P.E.D., Nesan, L.J. (2000), Employee Empowerment İn Construction: An İmplementation Model For Process İmprovement. Team Performance Management, Vol. 6 Nos 3/4, 47-51.

Hu, S.L.Y., Leung, L. (2003). Effects Of Expectancy-Value, Attitudes, And Use Of The Internet On Psychological Empowerment Experienced By Chinese Women At The Workplace. Telematics And Informatics, 20(4), 365-82

Janssen O., Schoonebeek G., Looy B. Van (1997). Cognities Van Empowerment Als De Schakel Tussen Delegerend Leiderschap En İnnovatief Gedrag Van Werknemers. Gedrag \& Organisatie, 10(4), 175-191. 


\section{İ. Çevik Tekin - T. Akgemci 11/3 (2019) 1674-1692}

Janssen, O. (2005). The Joint İmpact Of Perceived İnfluence And Supervisor Supportiveness On Employee İnnovative Behaviour. Journal Of Occupational And Organizational Psychology, 78:573-579.

Kaiser, H.F., Rice, J. (1974). Little Jiffy Mark İv. Educational And Psychological Measurement, 34, 111-117.

Kline, R. B. (2011). Convergence Of Structural Equation Modeling And Multilevel Modeling. In M. Williams, \& W. P. Vogt (Eds.), Handbook Of Methodological İnnovation, Thousand Oaks, Ca: Sage. 562-589.

Knol, J., Van Linge, R. (2009). Innovative Behaviour: The Effect Of Structuraland Psychological Empowerment On Nurses. Journal Of Advanced Nursing, 65(2):359-370).

Koçel, T. (2013). İşletme Yöneticiliği (14. Baskı). İstanbul: Beta Basım Yayım Dağıtım A.Ş

May, D.R., Gilson, R.L., Harter, L.M. (2004). The Psychological Conditions of Meaningfulness, Safety and Availability and The Engagement of The Human Spirit At Work. Journal of Occupational And Organizational Psychology,77(1), 11-37.

Menon, S.T. (2001). Employee Empowerment: an İntegrative Psychological Approach. Applied Psychology: An International Review, 50: 153-180.

Oktuğ, Z., (2014). Yenilikçilik ve Çalı̧̧maya Tutkunluk Çalışanı Güçlendirmenin Etkileri, İstanbul: Galata Yayınları.

Oukes, T. (2010). Innovative Work Behavior, University of Twente, Bachelor Thesis, Holland.

Örücü, E., Çınar, B., (2019). Pozitif Psikolojik Sermayenin Yenilikçi Davranış Üzerindeki Etkisi: Bankacılık Sektöründe Bir Araştırma, Anemon Muş Alparslan Üniversitesi Sosyal Bilimler Dergisi 2019 7(2) 287299.

Özdaşlı, K. (2005). Yaratıcılık mı Yoksa Taklit mi?: Yenilik Sürecinin Başlangıç Aşamasına İlişkin Bir Analiz. Süleyman Demirel Üniversitesi Sosyal Bilimler Enstitüsü Dergisi, Yı1:1, Sayı:2, 67-81.

Özkan, G. V. (2017). Çalışanların Özyeterlilik Düzeyinin Yaratıcı ve Yenilikçi İş Davranışlarına Etkisi: Farklı Sektörlerde Faaliyet Gösteren Örgütler Üzerinden Karşılaştırmalı Bir Değerlendirme. Journal Of Yasar University, 12(47), 181-191.

Pieterse, A., Nederveen, D., Van K., Michaéla S., Daan S. (2010); Transformational And Transactional Leadership And Innovative Behavior: The Moderating Role of Psychological Empowerment, Journal Of Organizational Behavior, Cilt 31, Say1 4, 609- 623.

Prieto, M.P., Perez-Santana, M.P. (2014). Managing İnnovative Work Behavior: The Role of Human Resource Practices. Personnel Review. 43(2). 184-208. Doi:10.1108/Pr-11- 2012-0199

Schermerhorn, J.R. (1999). Management. New York: John Wiley.

Schermerhorn, J.R., Hunt, J.G., Osborn, R.N. (2000). Organizational Behaviour (7th Ed.). Usa: John Wiley\&Sons, Inc.

Sekaran, U. (2000) Research Methods for Business: A Skill Business Approach. John Wiley \& Sons, New York.

Sigler, T.H., Pearson, C.M. (2000). Creating An Empowering Culture: Examining The Relationship Between Organizational Culture and Perception Of Empowerment. Journal of Qualty Management, Cilt 5, 27-52.

Spreitzer, G. (2007). Taking Stock: A Review Of More Than Twenty Years Of Research On Empowerment At Work. In The Handbook Of Organizational Behavior, C. Cooper And J. Barling Eds. Sage Publications.

Spreitzer, G.M. (1995). Psyhological Empowerment In The Workplace: Dimensions, Measurement, And Validation. Academy Of Managemet Journal, Cilt 38, Say1 5, 1442-1465.

Spreitzer, G.M. (1996). Social Structural Characteristics of Psychological Empowerment. The Academy Of Management Journal, Volume: 39, Number: 2, 483 - 504.

Şahin, A. (2009). Mersin'de Faaliyet Gösteren Küçük ve Orta Büyüklükteki İşletmelerin Yenilik Faaliyetlerinin Ölçülmesi. Doğuş Üniversitesi Dergisi, 10 (2), 259-271.

Şen, Y. (2008). Dönüşümcü Liderliğin Psikolojik Güçlendirme ve Örgütsel Bağlllık Üzerindeki Etkilerini Belirlemeye Yönelik Bir Araştırma. Yayınlanmamış Yüksek Lisans Tezi, İstanbul, İstanbul Üniversitesi Sosyal Bilimler Enstitüsü.

Tavşancıl E. (2014). Tutumların Ölçülmesi ve Spss İle Veri Analizi (5. Basım). Ankara: Nobel Yayınclık. 


\section{İ. Çevik Tekin - T. Akgemci 11/3 (2019) 1674-1692}

Thomas K.W., Velthouse B.A. (1990). Cognitive Elements Of Empowerment: An İnterpretive Model Of İntrinsic Task Motivation. Academy Of Management Review, Cilt 15, Sayı 4, 666-681.

Tolay, E., Sürgevil, O., Topoyan, M. (2012). Akademik Çalışma Ortamında Yapısal Ve Psikolojik Güçlendirmenin Duygusal Bağllık ve Is Doyumu Üzerindeki Etkileri. Ege Akademik Bakış, 12(4), 449.

Toplu, D., Akça, M. (2013). Öğrenen Organizasyonun Psikolojik Güçlendirme Üzerindeki Etkisi: Kamu Sektöründe Bir Araştırma, İstanbul Ticaret Üniversitesi Sosyal Bilimleri Dergisi, 12 (23), 221-235.

Turek, A. W. (2012). Innovative Work Behavior And Psychological Capital- Analysis Of Relationships. Organizacja İ Zarządzanie: Kwartalnik Naukowy, 3 (19), 71-88.

Uzunbacak, H. H. (2013). Organizasyonlarda Personel Güçlendirme Uygulamalarının, Çalışanların Yenilikçilik Davranışları Üzerine Etkisi: Bir Araştırma. Süleyman Demirel Üniversitesi, İşletme Bölümü, Doktora Tezi, 208 Sayfa, Mayıs.

Wang, C. L., Ahmed, P. K. (2004). The Development And Validation Of The Organisational İnnovativeness Construct Using Confimatory Factor Analysis. European Journal Of Innovation Management, Cilt 7, Say1 4, 303-313.

West, M. A. (2002). Sparkling Fountains or Stagnant Ponds: An Integrative Model of Creativity And Innovation Implementation İn Work Groups. Applied Psychology: An International Review, Vol: 51, 355 387

Wiens, S. (2012). Clinical İnstructors' Perceptions Of Structural And Psychological Empowerment İn Academic Nursing Environments (Unpublished Doctoral Dissertation). University Of Western Ontario, London, Ontario, Canada.

Young, P. V. (1968). Bilimsel sosyal incelemeler ve araştırma(Çev. G. Bingöl ve N.İşçil). Ankara: Ege Matbaasi.

Yuan, F., Woodman R. W. (2010). Innovative Behavior İn Theworkplace: The Role Of Performanceand Image Outcome Expectations. Academy of Management Journal, 53(2), 323-342. 